\title{
Parlamenter ve Başkanlık Sistemiyle Yönetilen Ülkelerde Gelir Dağılımı Eşitsizliği ve Yoksulluk
}

\author{
H. EMRE BAĞCE* \\ emrebagce@yahoo.com
}

Özet: Bu makalede parlamenter, başkanlık ve yarı başkanlık sistemiyle yönetilen ülkeler gelir dağılımı eşitsizliği ve yoksulluk bakımından incelenmektedir. Bu şekilde, yönetim sistemlerinin avantaj veya dezavantajlarına dair hipotetik tartışmaların aşılmasl, somut araştırma sonuçları üzerinden yönetim sistemlerinin niteliğine dair daha rafine bilgiye ulaşılması amaçlanmıştır. Çalışmanın ilk kısmında, dünyada hangi ülkelerin parlamenter sistemle, hangilerinin başkanlık ve yarı başkanlık sistemleriyle yönetildiği belirlenmiş ve tasnif edilmiştir. İkinci bölümde, yüz elliden fazla ülkenin gelir dağılımı eşitsizliği - Gini Endeksi (Dünya Bankası tahmini) yönetim sistemlerine göre gözden geçirilmiş ve karşılaştırılmıştır. Üçüncü bölümde ise Oxford Yoksulluk ve Insani Gelişme Girişiminin Çok Boyutlu Yoksulluk Endeksindeki yüz bir ülkenin yoksulluk seviyesi rakip siyasi sistemlere bağlllıkları açısından incelenmiştir. Çalışmanın sonuçlarına göre, parlamenter sistemle yönetilen ülkelerde gelir dağılımı eşitsizliğinin daha az olduğu, bu ülkelerin benzer şekilde yoksulluk açısından da daha olumlu durumda olduğu tespit edilmiştir. Başkanlık ve yarı başkanlık ülkelerinin ise bilakis her iki kategoride de olumsuz durumda bulunduğu belirlenmiştir.

Anahtar Kelimeler: Parlamenter sistem, Başkanlık sistemi, Yarı başkanlık sistemi, Gelir dağılımı eşitsizliği, Gini endeksi, Yoksulluk.

\section{Giriş}

BM'ye tam üye sıfatıyla kayıtlı 193 ülke bulunuyor; Hong Kong, Kuzey Kıbrıs, Porto Riko, Filistin, Makao gibi bağlı, özerk veya kısmen tanınmış ülkeler hesaba katıldığında dünyadaki ülke sayısı 200'ü aşmaktadır. Ülkelerin rejimlerinden veya yönetim sistemlerinden söz edildiğinde monarşi veya cumhuriyet, başka ayrımlara göre demokratik veya otoriter/totaliter rejimler şeklinde sınıflandırmalar yapılmaktadır. Antik dönemlerden itibaren yönetimlere dair monarşi, aristokrasi (bazen oligarşi) ve demokrasi ayrımı yaygın şekilde kullanılmaktadır. Bu sınıflamalarda iktidarın dayandığı temel, halkın katılımı ve kamu yararı gibi faktörler belirleyici olmaktadır. Öyle ki, Platon ve Aristoteles’te nicelik olarak yönetime katılan kişi sayısı kadar

\footnotetext{
* Prof. Dr., Marmara Üniversitesi, İletişim Fakültesi.

$\mathrm{Bu}$ çalışmada ele alınan meseleler yazarın Parlamenter Sistem mi, Başkanlık mı?: Yoksulluktan Hukukun Üstünlüğüne Ülkelerin Dünyadaki Yeri (İstanbul: Gonca Yayınevi), 2016 başlıklı eserinde kapsamlı şekilde incelenmiştir. Bu makalede bilgiler gözden geçirilmiş, yeni eklenen tablo ve grafiklerle yönetim sistemleri arasında daha fazla karşılaştırma imkânı sağlanmıştır.
} 
yönetimin halkın tümünün, yani kamunun, yararını gözetip gözetmemesi, yasalara saygılı olup olmaması gibi nitelikler yönetimleri ayrıştırmak için vazgeçilmez görülmüştür. Yeniçağ ile birlikte yönetimler monarşi, aristokrasi, demokrasi şeklinde sadece yönetimde bulunan kişi sayısına bakılarak tarif edilmeye başlanmıştır. Ancak cumhuriyetin yaygınlaşması sonucu bu ayrım yönetimleri sınıflandırmak ve tarif etmek açısından yetersiz kalmıştır. Bu kapsamda yönetim içinde özellikle yasama ve yürütme ilişkilerinin düzenlenişine göre tasnifler gelişmiştir. Parlamenter, başkanlık veya yarı başkanlık olarak nitelenen ülkelerin, kimi yerleşik kimi zayıf olmakla birlikte, cumhuriyet ve demokrasi çatısı altında yer aldığı söylenebilir. Elbette bu, o ülkelerin iç karışıklıklar, isyanlar, darbeler yaşamayacağı veya otoriter sapmalar göstermeyeceği anlamına gelmiyor. Bu bakımdan demokratik ve otoriter/totaliter ayrımını her zaman göz önünde bulundurmak gerekiyor. Parlamenter ve başkanlık sistemi esas olarak yürütmenin belirlenmesine, konumuna ve yasama ile ilişkilerine göre şekil alır. Bir ülkede parlamenter, başkanlık veya yarı başkanlık sistemine dair tercihler, o ülkedeki siyasi kurumsallaşma biçimini ve siyasi kültürü şekillendirir; siyasetin işleyişini ve sonuçlarını derinden etkiler.

$\mathrm{Bu}$ makalede ülkelerin uyguladıkları yönetim sistemi ile toplumdaki gelir dağılımı eşitsizliği ve yoksulluk durumu arasındaki ilişki değerlendirilecektir. Yani yönetim sistemlerine göre ülkelerin gelir dağılımı eşitsizliği seviyesinin ne olduğu; yoksulluğun hangi boyutlarda bulunduğu sorusuna cevap aranacaktır. Bu soruya cevap verebilmek için öncelikle her bir yönetim sisteminde hangi ülkelerin bulunduğu tespit edilecektir. İkinci bölümde yönetim sistemlerine göre dünyada gelir dağıllmı eşitsizliği, üçüncü bölümde ise yönetim sistemlerine göre ülkelerin yoksulluk durumu ele alınacaktır. Gelir dağılımı eşitsizliğini belirlemek amacıyla esas olarak Dünya Bankası'nın 2015 Gini Endeksi'nden yararlanılacaktır. Dünyada yoksul ülkelerin yönetim sistemlerine göre durumunu tespit edebilmek amacıyla da, Oxford Yoksulluk ve İnsani Gelişme Girişimi (Oxford Poverty and Human Development Initiative - OPHI) ile Birleşmiş Milletler Kalkınma Programı İnsani Gelişme Raporu tarafından hazırlanan Çok Boyutlu Küresel Yoksulluk Endeksi kullanılacaktır'1. Her iki bölümde endekste yer alan tüm ülkelerin analizine ek olarak, üç yönetim sisteminden tabakalı olarak seçilen 25’er ülkenin (toplam 75 ülke) verileri üzerine ikinci bir analiz gerçekleştirilecektir. Bu yolla, yönetim sistemlerinin performanslarına dair daha rafine sonuçlara ulaşılacaktır. Çalışmada ayrıca Türkiye’nin endeksteki yerine ve gelir dağılımı eşitsizliği bakımından ne durumda olduğuna kısaca değinilecektir.

Endeks değerlerinin yönetim sistemlerine göre ayrıştırılarak incelenmesi literatüre özgün ve önemli bir katkı sağlamaktadır. Bu yolla, 'yönetim sistemleri nedir', 'avantaj veya dezavantajları nelerdir' şeklindeki kitabi, birçok durumda hipotetik ve ideolojik tartışmaların ötesine geçilebilecektir. Yönetim sistemlerinin ürettiği sonuçların ayrıntılı analiziyle yönetim sistemlerinin yapı, işleyiş ve niteliğine dair daha sağlıklı değerlendirme yapma imkânı doğacaktır.

1 Ülkelerin, karşılaştırma yapmaya imkân verecek şekilde, yönetim sistemlerine göre sınıflanmış verileri makalenin sonunda Tablo 5 ve Tablo 6'da yer almaktadır. 


\section{Dünyada Hangi Ülkeler Nasıl Yönetiliyor?}

Ülkelerin yönetim sistemlerine göre tasnif edilmesi hayli uğraş gerektiren bir iş. Bunun birçok nedeni bulunmaktadır; en başta ise ülkelerin yaşadığı değişiklikler gelmektedir. Tarihsel seyir içinde olağan veyahut olağan dışı koşullarda ülkelerin yönetim sistemleri değişmekte, dönüşmektedir. Ayrıca yönetim sistemlerine yönelik tasnifler bazen sınırlı düzeyde kalmakta, bazen de hatalar ihtiva edebilmektedir. Güncel veriler dikkate alındığında, 86 ülkenin parlamenter sistemle, 59 ülkenin başkanlıkla, 41 ülkenin ise yarı başkanlıkla yönetildiği görülmektedir²

Parlamenter sistemde, yürütme parlamento içinden belirlenmekte, kabine parlamentoya karşı sorumlu kılınmaktadır. Genel olarak bakanlar ve özelde başbakan milletvekili oldukları için, başbakan eşitler arasında birinci rolü oynamaktadır. $\mathrm{Bu}$ durum beraberinde hükümet üyelerinin hem tek tek, hem de ortak sorumluluğunu getirmektedir. Cumhurbaşkanı parlamenter sistemde devlet başkanı sıfatıyla yasama-yürütme-yargı kuvvetleri arasında dengeleyici ve uzlaştırıcı bir rol oynamakta hem de yürütme içinde gücü dengelemek ve denetlemek için ayrıca sembolik bir rol oynamaktadır. Bu nedenlerle parlamenter sistemlerde cumhurbaşkanının rolü parlamenter sistemin beşiği sayılan İngiltere’de kral veya kraliçenin oynadığı role denk bulunmaktadır; sembolik, törensel, toplumda ve kurumlar arasında birleştirici, uzlaştırıcı bir konum. Yasama-yürütme arasında ve yürütmenin kendi içindeki bu tür yumuşak düzenlemelerden dolayı parlamenter sistemde yasama-yürütme ilişkileri esnektir. Parlamenter sistem ile başkanlık sisteminin farklarını görmek için başkanlık sisteminin ayırt edici özelliklerine bakmak gerekir: Başkanlık sisteminde yasama ve yürütme ayrı seçimlerle ve belirli süreler için belirlenir; bu sistemde başbakan başkanlığında parlamento içinden seçilen ve parlamentoya karşı sorumlu olan bir bakanlar kurulu bulunmaz, yani yürütme tek kişide toplanır. Yarı başkanlık sistemleri ise başkanlıktan ziyade parlamenter sistem içinde yer alır. Temel farklılığı yürütme içinde cumhurbaşkanı ile başbakan arasındaki güç dengesinin cumhurbaşkanı lehine ağırlık kazanmasıdır. Yani yarı başkanlık sistemlerinde cumhurbaşkanı sembolik olmaktan ziyade yürütmenin başı olarak etkili bir rol oynar. Başbakan ve bakanlar kurulu ikinci konumda kalır³.

Parlamenter sistemde cumhurbaşkanı, Almanya ve İtalya'da olduğu gibi parlamento tarafından seçildiği gibi, Avusturya, İzlanda, Finlandiya gibi örneklerde olduğu gibi halk tarafından doğrudan seçimlerle de belirlenebilir. Bazı akademisyenler cumhurbaşkanının halk tarafından seçilmesini yarı başkanlık sistemi olarak sunma eğilimi göstermektedir; hâlbuki seçimden ziyade yukarıda belirtildiği üzere cumhurbaşkanının oynadığ 1 rol parlamenter ve yarı başkanlık sistemi arasındaki farkı meydana getirmektedir. Hatta bir dönemler yarı başkanlık sistemi içinde sayılan Polonya ve

2 Bkz., Bağce, Parlamenter Sistem mi, Başkanlık mı?, 25-27.

3 Bağce, Parlamenter Sistem mi, Başkanlık mı?, 1. Bölüm: “Ülkeler ve Yönetim Sistemleri”, 15-29; yönetim sistemlerine dair ayrıca bkz., H. Emre Bağce, "Parlamenter ve Başkanlık Sistemiyle Yönetilen Ülkelerde İstikrar Durumu”, Köprü, 136 (2016): 23-36; H. Emre Bağce, “The Role of Political Institutions in Tackling Political Fragmentation and Polarization: Presidentialism versus Parliamentarism", C. Ü. İktisadi ve İdari Bilimler Dergisi, 3/1 (2002): 147-162; Tuğrul Korkmaz, "Hükümet Sistemleri ve Türkiye Üzerine Bir Analiz", Akademik Hassasiyetler Dergisi 3/6 (2016): 43-57. 
Finlandiya gibi ülkelerin Avrupa Birliği sürecinde yarı başkanlıktan parlamenter sisteme geçişlerinin gösterdiği üzere ${ }^{4}$, parlamenter ülkelerde sembolik monarşiler $\mathrm{d}_{1}$ şında meclis veya halk tarafından seçilen ve sembolik rol oynayan cumhurbaşkanları bulunmaktadır 5 .

Aşağıdaki listeden ve makalenin sonunda yer alan Liste 4’ten takip edileceği üzere, başta Avrupa ülkeleri, Kanada, Japonya olmak üzere dünyada irili ufaklı pek çok ülke parlamenter sistemi benimsemiştir.

\section{Liste 1. Parlamenter Sistemle Yönetilen Ülkeler}

$\begin{array}{lll}\text { Almanya } & \text { Hindistan } & \text { Malta } \\ \text { Andorra } & \text { Hollanda } & \text { Marşal Adaları } \\ \text { Antigua ve Barbuda } & \text { Irak } & \text { Mauritius } \\ \text { Arnavutluk } & \text { İngiltere } & \text { Moldova } \\ \text { Avustralya } & \text { İrlanda } & \text { Monako } \\ \text { Avusturya } & \text { İspanya } & \text { Nauru } \\ \text { Bahamalar } & \text { İsrail } & \text { Nepal } \\ \text { Bahreyn } & \text { İsveç } & \text { Norveç } \\ \text { Bangladeş } & \text { İsviçre } & \text { Pakistan } \\ \text { Barbados } & \text { İtalya } & \text { Papua Yeni Gine } \\ \text { Belçika } & \text { İzlanda } & \text { Saint Kitts ve Nevis } \\ \text { Belize } & \text { Jamaika } & \text { Saint Lucia } \\ \text { Birleşik Arap Emir. } & \text { Japonya } & \text { Saint Vincent ve Grenadinler } \\ \text { Bosna Hersek } & \text { Kamboçya } & \text { Samoa } \\ \text { Botsvana } & \text { Kanada } & \text { San Marino } \\ \text { Bulgaristan } & \text { Karadağ } & \text { Singapur } \\ \text { Butan } & \text { Kirgızistan } & \text { Slovakya } \\ \text { Çek Cumhuriyeti } & \text { Kiribati } & \text { Slovenya } \\ \end{array}$

$4 \mathrm{Bu}$ hususta, BM ile benzer bir statüde bulunan Parlamentolar Arası Birliğin (PAB) veri tabanı muhtemel karışıklıkları giderecek niteliktedir. Makalenin sonunda Liste 4’te "Parlamentolar Arası Birlik Verilerine göre Avrupa Ülkelerinin Yönetim Sistemi” yer almaktadır. Bu listede Avrupa ülkelerinin birkaç istisna dışında parlamenter sistemi benimsediği görülmektedir. Buna rağmen, bu çalışmada Polonya’nın eski tasniflerde yarı başkanlık içinde sayılması da göz önüne alınarak yarı başkanlık ülkeleri arasında değerlendirilmiştir. Çalışma sonuçlarında bu hususun nasıl bir etkide bulunacağı göz önünde bulundurulmalıdır.

5 Bağce, Parlamenter Sistem mi, Başkanlık mı?, 15 vd. Bağce, "Parlamenter ve Başkanlık Sistemiyle...."

6 William Roberts Clark, Matt Golder, Sona Nadenichek Golder, Principles of Comparative Politics, 2. Baskı, Los Angeles, London, New York: Sage Publications, 2013, 465.

7 “Government”, The Government of the Republic of Nauru, http://www.naurugov.nr/government.aspx, (Erişim: 4 Şubat 2016). Ayrıca, bkz. "Information about the President's Office”, The Government of the Republic of Nauru, http://www.naurugov.nr/government/the-president's-office.aspx, (Erişim: 4 Şubat 2016). Başbakan’ın başkan terimi ile anılıyor olması okuru yanıltmamalı. Ülke başkanlıkla değil, parlamenter sistem ile yönetilmektedir.

8 "Switzerland's Political System", The Federal Council: The Portal of the Swiss Government, https://www.admin. ch/gov/en/start/federal-council/political-system-of-switzerland.html, (Erişim: 2 Şubat 2016). Roberto Gándara Sánchez, "Parliamentary and Presidential Systems", Puerto Rico Encyclopedia, http://www.enciclopediapr.org/ ing/article.cfm?ref=13010903, 11 Eylül 2014 (Erişim: 2 Şubat 2016).

9 "Organisation Structure", Parliament of Singapore, https://www.parliament.gov.sg/organisation-structure, (Erişim: 3 Şubat 2016).

10 “State: Political System", Slovania.Si, http://www.slovenia.si/slovenia/state, (Erişim: 5 Şubat 2016). "Political System", Government of the Republic of Slovenia, http://www.vlada.si/en/about_slovenia/political_system, 


$\begin{array}{lll}\text { Danimarka } & \text { Kosova } & \text { Solomon Adaları } \\ \text { Dominika } & \text { Kuveyt } & \text { Tayland } \\ \text { Estonya } & \text { Lesoto } & \text { Tonga } \\ \text { Etiyopya } & \text { Letonya } & \text { Trinidad ve Tobago } \\ \text { Fas } & \text { Lihtenştayn } & \text { Tuvalu } \\ \text { Fiji } & \text { Litvanya } & \text { Türkiye } \\ \text { Finlandiya } & \text { Lübnan } & \text { Ürdün } \\ \text { Grenada } & \text { Lüksemburg } & \text { Vanuatu } \\ \text { Guyana } & \text { Macaristan } & \text { Yeni Zelanda } \\ \text { Güney Afrika } & \text { Makedonya } & \text { Yunanistan } \\ \text { Hirvatistan } & \text { Malezya } & \end{array}$

Yarı başkanlıkla yönetilen ülkeler büyük ölçüde Fransa, Portekiz ve geçmişte bu ülkelerin sömürgesi olan ülkelerden meydana gelmektedir. Yarı başkanlık içinde tasnif edilen Polonya yarı başkanlıktan parlamenter sisteme doğru geçiş yapmış, AB’nin büyük çoğunluğunda olduğu gibi parlamenter sistem içinde yer almıştır. Sovyet Blokunun dağılmasından sonra yarı başkanlıkla yönetilen Kırgızistan ise 2000'li yıllarda yaşadığı siyasi karışıklıklardan sonra cumhurbaşkanının yetkilerini sembolik bir rolle sinırlandırarak parlamenter sisteme geçmiştir. Asya ülkelerinden Moğolistan halen yarı başkanlıktan parlamenter sisteme doğru bir süreç yaşamaktadır ${ }^{12}$.

\section{Liste 2. Yarı Başkanlık Sistemiyle Yönetilen Ülkeler}

\begin{tabular}{|c|c|c|}
\hline Burkina Faso & $\operatorname{Iran}^{13}$ & Romanya \\
\hline Cezayir & Kamerun $^{14}$ & Rusya \\
\hline Cibuti $^{15}$ & Kuzey Kıbris & Sao Tome ve Principe \\
\hline Çin ${ }^{16}$ & Madagaskar & Senegal \\
\hline Demokratik Kongo & Mali & Sirbistan \\
\hline Doğu Timor & Misir & Sri Lanka \\
\hline Ermenistan $^{17}$ & Moğolistan & Suriye \\
\hline Filistin & Moritanya & Tanzanya $^{18}$ \\
\hline
\end{tabular}

(Erişim: 5 Şubat 2016).

11 "Prime Ministry", The Hashemite Kingdom of Jordan: The Official Site of the Jordanian e-Government, http:// www.jordan.gov.jo/wps/portal/!ut/p/b1/04_SjzQ0tjS1NLYwNNCP0I_KSyzLTE8syczPS8wB8aPM4sMsvS3CvN0NDSw83C0MPL0MjMx8zZ2MDVwN9YNT8_RzoxwVAdrPvkU!/?nameEntity=The\%20Prime\%20Ministry, (Erişim: 3 Şubat 2016).

12 Ayrıntılar ve dünyadaki eğilim için bkz., Bağce, Parlamenter Sistem mi, Başkanlık mı?, 1. Bölüm: "Ülkeler ve Yönetim Sistemleri”, 15 vd. Bağce, "Parlamenter ve Başkanlık Sistemiyle...”.

13 "Islamic Republic of Iran: An Islamic Popular System (13)", Iran English Radio, http://english.irib.ir/analysis/ articles2/item/169658-islamic-republic-of-iran,-an-islamic-popular-system-13, (Erişim: 2 Şubat 2016). Lowell Barrington, Comparative Politics: Structures and Choices, 2. Baskı, Wadsworth: Cengage Learning, 2012, 26. 14 “Government”, Services du Premier Ministre du Cameroun, http://www.spm.gov.cm/en/government.html, (Erişim: 5 Şubat 2016).

15 “Djibouti: Government”, Global Edge, Michigan State University, http://globaledge.msu.edu/countries/ djibouti/government, (Erişim: 4 Şubat 2016).

16 Barrington, Comparative Politics, 188.

17 "Government System", The Government of the Republic of Armenia, http://www.gov.am/en/gov-system, (Erişim: 6 Şubat 2016).

18 “The Cabinet: 12 December 2015 - Present”, Embassy of Tanzania, Germany, http://www.tanzania-gov.de/ tanzania/the-cabinet, (Erişim: 2 Şubat 2016). 


$\begin{array}{lll}\text { Fransa } & \text { Namibya }^{19} & \text { Tayvan }^{20} \\ \text { Gabon } & \text { Nijer } & \text { Togo } \\ \text { Gine Bissau } & \text { Orta Afrika } & \text { Tunus } \\ \text { Gürcistan } & \text { Peru } & \text { Ukrayna } \\ \text { Haiti } & \text { Polonya } & \text { Yeşil Burun } \\ \text { Hong Kong } & \text { Portekiz } & \end{array}$

Dünyada 59 ülke başkanlık sistemiyle yönetilmektedir. Bu ülkelerin ağırlıklı kısmı Latin Amerika, Afrika, Orta Asya ile Filipinler ${ }^{22}$ ve Endonezya gibi Asya Pasifik ülkelerinden oluşmaktadır.

Liste 3. Başkanlı Sistemiyle Yönetilen Ülkeler

$\begin{array}{lll}\text { Afganistan } & \text { Gine } & \text { Nikaragua } \\ \text { Amerika Bir. Dev. } & \text { Guatemala } & \text { Özbekistan } \\ \text { Angola } 23 & \text { Güney Kore } & \text { Palau } \\ \text { Arjantin } & \text { Güney Sudan } & \text { Panama } \\ \text { Azerbaycan }{ }^{24} & \text { Honduras } & \text { Paraguay } \\ \text { Belarus } & \text { Kazakistan } & \text { Porto Riko } \\ \text { Benin } & \text { Kenya } & \text { Ruanda } \\ \text { Bolivya } & \text { Kibris } & \text { Seyşeller } \\ \text { Brezilya } & \text { Kolombiya } & \text { Sierra Leone } \\ \text { Burundi } & \text { Komor } & \text { Sudan } \\ \text { Çad } & \text { Kongo } & \text { Surinam } \\ \text { Dominik Cum. } & \text { Kosta Rika } & \text { Şili } \\ \text { Ekvator } & \text { Liberya } & \text { Tacikistan } \\ \text { Ekvator Ginesi } & \text { Malavi } & \text { Türkmenistan } \\ \text { El Salvador } & \text { Maldivler } & \text { Uganda } \\ \text { Endonezya } & \text { Meksika } & \text { Uruguay }\end{array}$

19 “Executive Branch", Government of Namibia, http://www.gov.na/executive, (Erişim: 6 Şubat 2016).

20 Benjamin Reilly, "Semi-presidential democracy in East Asia”, East Asia Forum: Economics, Politics and Public Policy in East Asia and the Pacific, http://www.eastasiaforum.org/2008/11/08/semi-presidentialism-anddemocratic-development-in-east-asia-grows (Erişim: 2 Şubat 2016).

21 Matthew Søberg Shugart, "Semi-Presidential Systems: Dual Executive And Mixed Authority Patterns”, French Politics, 2005, 3, 323-351. Robert Elgie, "What is Semi-Presidentialism and Where is It Found?", Robert Elgie ve Sophia Moestrup (ed.), Semi-Presidentialism Outside Europe: A Comparative Study, London, New York: Routledge, 2007. Clark vd. ise Peru’yu başkanlık sistemi içinde sinıflandırmaktadır, bkz., Clark, Golder ve Golder, Principles of Comparative Politics, 465.

22 Parlamenter sistemle yönetilen Malezya ile başkanlık sistemi ile yönetilen Filipinler üzerine istikrar konusunda yapılmış bir çalışma için bkz., Bağce, "The Role of Political Institutions...”

23 "Government: Overview", Embassy of Angola Washington D.C., http://www.angola.org/index. php?page=overview, (Erişim: 2 Şubat 2016). "Angola Country Profile”, BBC News, http://www.bbc.com/news/ world-africa-13036732, 11 Ocak 2016, (Erişim: 2 Şubat 2016). “Angola”, Freedom House, https://freedomhouse. org/report/freedom-world/2015/angola, (Erişim: 2 Şubat 2016).

24 "General Information on the Political System of AR", Azerbaycan Respublikasının Ali Mahkemesi, http:// www.supremecourt.gov.az/en/static/view/1, (Erişim: 2 Şubat 2016). 


$\begin{array}{lll}\text { Fildişi Sahili }^{25} & \text { Mikronezya }^{26} & \text { Venezuela } \\ \text { Filipinler } & \text { Mozambik } & \text { Zambiya } \\ \text { Gambiya } & \text { Myanmar (Burma) } & \text { Zimbabve } \\ \text { Gana }^{27} & \text { Nijerya } & \end{array}$

\section{Yönetim Sistemlerine Göre Dünyada Gelir Dă̆ılımı Eşitsizliği}

Ülkelerin gelir dağılımı eşitliği bakımından ne durumda olduğunu ölçmek için Gini endeksinden yararlanılmaktadır. Endeks İtalyan istatistikçi ve sosyolog Corrado Gini tarafından geliştirilmiş olduğu için bu adla anılmaktadır. Milli gelirin kişiler veya hane halkı arasında dağılımında tam eşit dağılıma ne ölçüde yaklaştığını veya ne ölçüde saptığını belirler. Teknik olarak, Gini endeksi veya katsayısı Lorenz eğrisinin ${ }^{28}$ üstündeki alanın, hipotetik tam eşitlik çizgisinin altında kalan üçgen alana bölünmesiyle bulunur. Yani,

Gini Endeksi = (Alan A) / (Alan A + Alan B) formülü ile hesaplanmaktadır.

\section{Grafik 1. Lorenz Eğrisi ve Gini Endeksi}

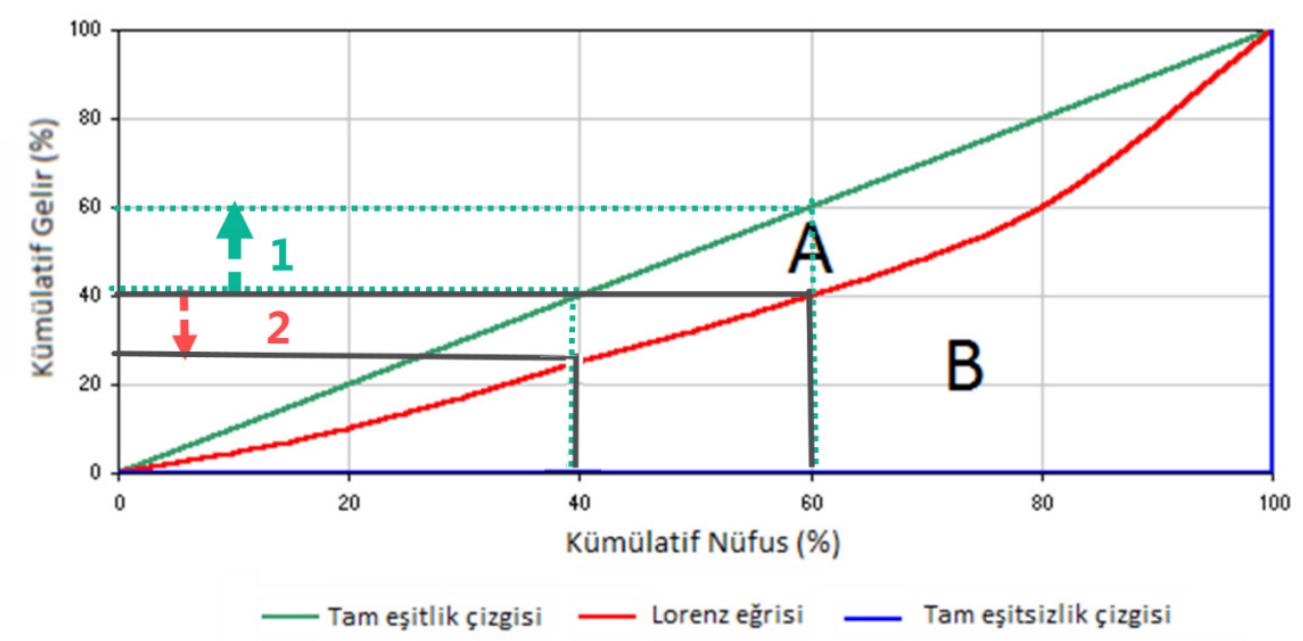

Gini Endeksi'nde 0 değeri tam eşitliği, 1 veya 100'lük sisteme göre 100 değeri ise tam eşitsizliği ifade eder. Yukarıda yer alan grafikte, örneğin, nüfusun yüzde 40-60 arasındaki yüzde 20'lik diliminin 1 no'lu aralıktaki yüzde 20'lik geliri değil, 2 no'lu aralıktaki daha küçük bir gelir dilimini aldığı görülüyor. Yine grafikte, nüfusun yüz-

25 “Côte D'ivoire: Public Administration Country Profile”, United Nations Division for Public Administration and Development Management (DPADM), Department of Economic and Social Affairs (DESA), September 2007, Çevrimiçi: http://unpan1.un.org/intradoc/groups/public/documents/un/unpan028168.pdf, (Erişim: 2 Şubat 2016).

26 "Executive Branch", Government of the Federated States of Micronesia, http://www.fsmgov.org/ngovt.html, (Erişim: 3 Şubat 2016).

27 “The Executive Powers of State”, The Presidency, Republic of Ghana, http://www.presidency.gov.gh/executive, (Erişim: 3 Şubat 2016).

28 Lorenz eğrisi ile ilgili bilgi için bkz., Joseph L. Gastwirth, “The Estimation of the Lorenz Curve and Gini Index", The Review of Economics and Statistics, 54/ 3 (1972): 306-316. Lorenz eğrisiyle ilgili bir örnek için bkz., TÜİK, "Gelir ve Yaşam Koşulları Araştırması, 2012: En Zengin Kesimin Geliri En Yoksul Kesimin Gelirinin 8 Katı Oldu”, Türkiye İstatistik Kurumu Haber Bülteni, 13594, 23 Eylül 2013, http://www.tuik.gov.tr/ PreHaberBultenleri.do?id=13594 (Erişim: 19 Ekim 2016). 
de 60'ının toplam gelirin ancak yüzde 40'ını aldığı, öte yandan nüfusun yüzde 80100 dilimindeki yüzde 20'lik kısmın toplam gelirin yüzde 40'ına sahip olduğu görülüyor. Gelirin tam eşit dağıtılması durumunda Lorenz eğrisi tam eşitlik çizgisi ile örtüşeceğinden Gini endeksinin değeri 0 olacaktır. Tam eşitsizlik halinde ise Lorenz eğrisi mavi çizgi ile örtüşeceğinden Gini katsayısı 1 olacaktır, diğer bir ifadeyle öyle bir durumda hipotetik olarak o ülkede bir tek kişi tüm gelire sahip olacaktır.

Çalışmada Dünya Bankası'nın 2015 Gini Endeksi tahminleri' ${ }^{29}$ kullanılmış; fakat beş ülkeyle ilgili eksik veya daha güncel veriler diğer uluslararası kaynaklardan derlenmiştir ${ }^{30}$.

\section{a) 161 Ülkede Gelir Dağılımı Eşitsizliği}

Çalışma kapsamında 161 ülkenin gelir dağılımı incelenmiştir. Tablo 1'de yönetim sistemlerine göre sınıflandırılmış ülke bilgileri, ortalama endeks değerleri, ortalama altında ve üstünde kalan ülke sayıları ile oranları yer almaktadır. Yönetim sistemlerine göre ülkelerin dünyadaki sırası ve endeks değerleri ise makalenin sonunda, Tablo 5 'ten takip edilebilir.

Tablo 1. Dünyada Gelir Dă̆ılımı Eşitsizliği: Yönetim Sistemlerine Göre Sonuçlar (161 Ülke)

\begin{tabular}{|c|c|c|c|c|c|c|c|c|}
\hline Yönetim sistemi & 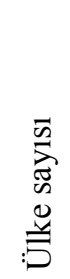 & 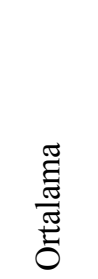 & 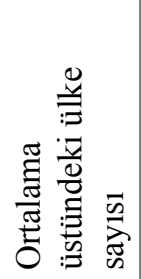 & 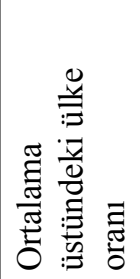 & 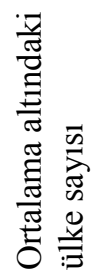 & 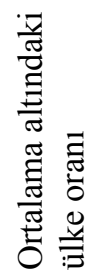 & 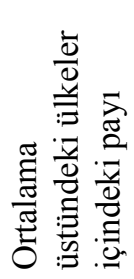 & 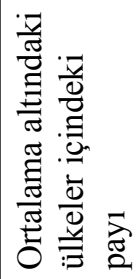 \\
\hline Parlamenter & 64 & 35,73 & 48 & 75 & 16 & 25 & 55,81 & 21,33 \\
\hline Yarı Başkanlık & 38 & 39 & 21 & 55,26 & 17 & 44,74 & 24,42 & 22,67 \\
\hline Başkanlık & 54 & 43,63 & 14 & 25,93 & 40 & 74,07 & 16,28 & 53,33 \\
\hline Diğer & 5 & 41,02 & 3 & 60 & 2 & 40 & 3,49 & 2,67 \\
\hline Dünya & 161 & 39,32 & 86 & & 75 & & 100 & 100 \\
\hline
\end{tabular}

Gini Endeksi’ne göre gelir dağılımı eşitsizliği ölçülen 161 ülke içinde parlamenter sistemle yönetilen ülkeler 35,73 ve yarı başkanlık sistemiyle yönetilen ülkeler 39 ortalama ile 39,32 olan dünya ortalamasının üstünde yer almaktadır. Başkanlık sistemiyle yönetilen ülkeler ise 43,63 ortalama ile dünya ortalamasının altında kalmaktadır.

29 "2015 World Development Indicators: Distribution of Income or Consumption", The World Bank, http://wdi. worldbank.org/table/2.9, Son Güncelleme: 16.12.2015. (Erişim: 26 Ocak 2016).

30 Afganistan, Azerbaycan, Katar ve Güney Sudan’ın Gini Endeksi bilgileri için bkz., "Income Gini Coefficient”, United Nations Development Programme, Human Development Reports, http:/hdr.undp.org/es/content/ income-gini-coefficient, (Erişim: 28 Ocak 2016). Zimbabwe’nin Gini Endeksi bilgisi için bkz., "Distribution of Family Income - Gini Index", CIA The World Factbook, https://www.cia.gov/library/publications/the-worldfactbook/fields/2172.html, (Erişim: 5 Şubat 2016). 
Grafik 2. Dünyada Gelir Dă̆ılımı Eşitsizliği: Yönetim Sistemlerine Göre Ülke Ortalamaları

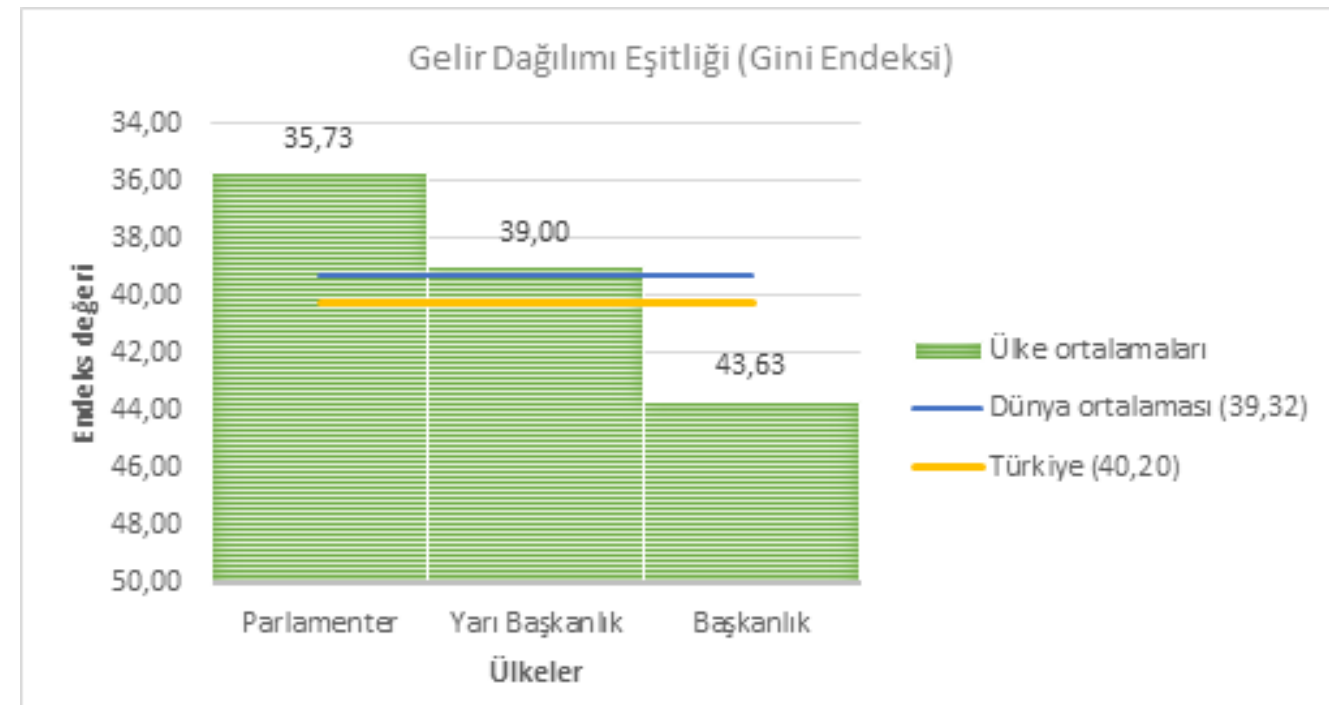

Türkiye Gelir Dağılımı Eşitliği Endeksi'nde 40,2 puan ile parlamenter ve yarı başkanlık sistemiyle yönetilen ülkelerin ve dünya ortalamasının altında bulunmaktadır. Ancak başkanlık ülkelerinin üzerinde yer almaktadır.

Grafik 3. Dünyada Gelir Dă̆ılımı Eşitsizliği: Yönetim Sistemlerine Göre Ortalama Üstündeki Ülkelerin Oranı

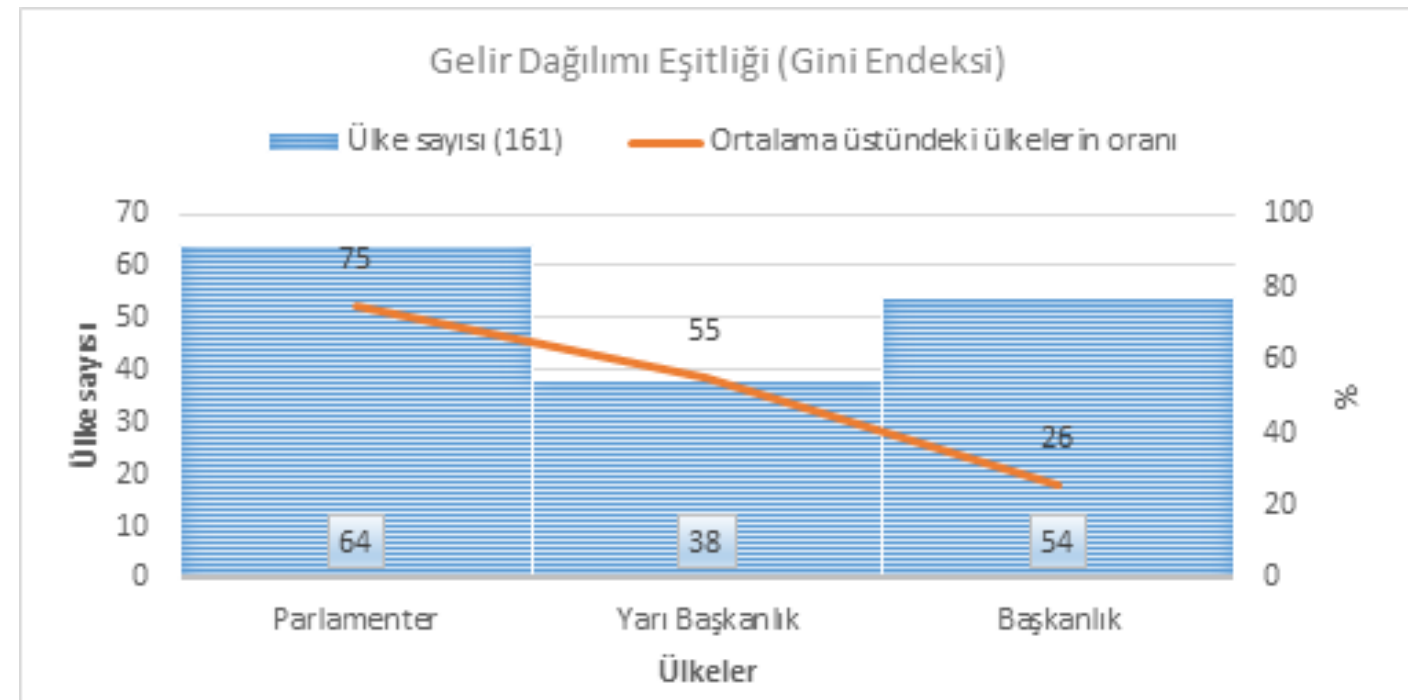

Gini Endeksi'nde, parlamenter sistemle yönetilen ülkelerin yüzde 75 ’i, yarı başkanlıkla yönetilenlerin yüzde 55’i ve başkanlık sistemiyle yönetilen ülkelerin yüzde 26’sı dünya ortalamasını aşıyor. 
Grafik 4. Dünyada Gelir Dağılımı Eşitsizliği: Yönetim Sistemlerinin Ortalama Üstündeki Ülkeler İçindeki Payı

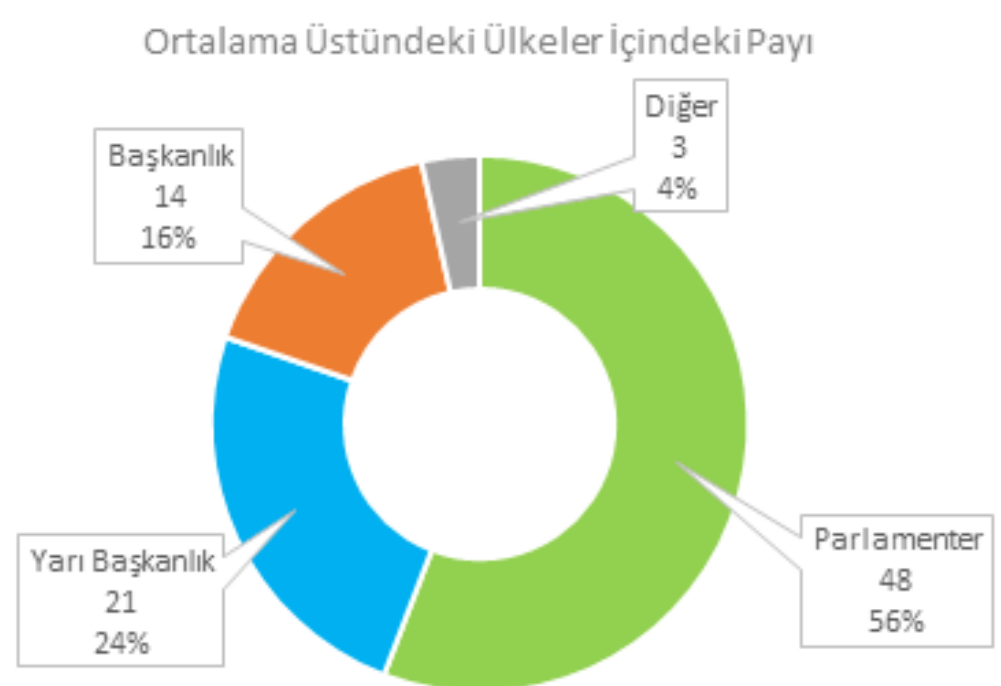

Grafik 5. Dünyada Gelir Dağılımı Eşitsizliği: Yönetim Sistemlerinin Ortalama Altındaki Ülkeler İçindeki Payı

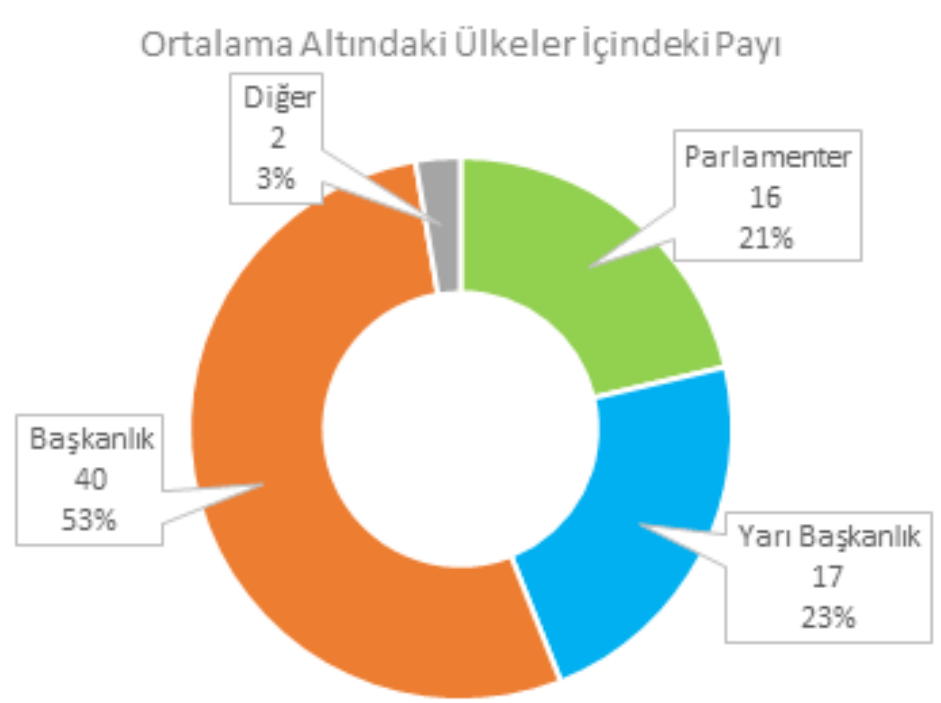

Ortalama üstündeki ülkeler içinde parlamenter sistemin payı yüzde 56, başkanlık sisteminin ise yüzde 16 'dır. Ortalama altındaki ülkelerde parlamenter sistemle yönetilen ülkeler yüzde 21 ile görece düşük paya sahip; başkanlık sistemi ile yönetilen ülkeler ise yüzde 53 ile gelir dağılımı eşitsizliğinin en yoğun yaşandığ grubu oluşturuyor.

Her bir yönetim içinde kaç ülke bulunduğu kadar bu ülkelerin gelir dağılımı eşitsizliğinde hangi düzeylerde olduğu da önemlidir. Aşağıdaki grafik yönetim sistemlerini bu bakımdan mukayese etmeye imkân vermektedir. 
Grafik 6. Dünyada Gelir Dağılımı Eşitsizliği: Yönetim Sistemlerine Göre Ülkelerin Dağılımı ve Eşitsizlik Seviyesi

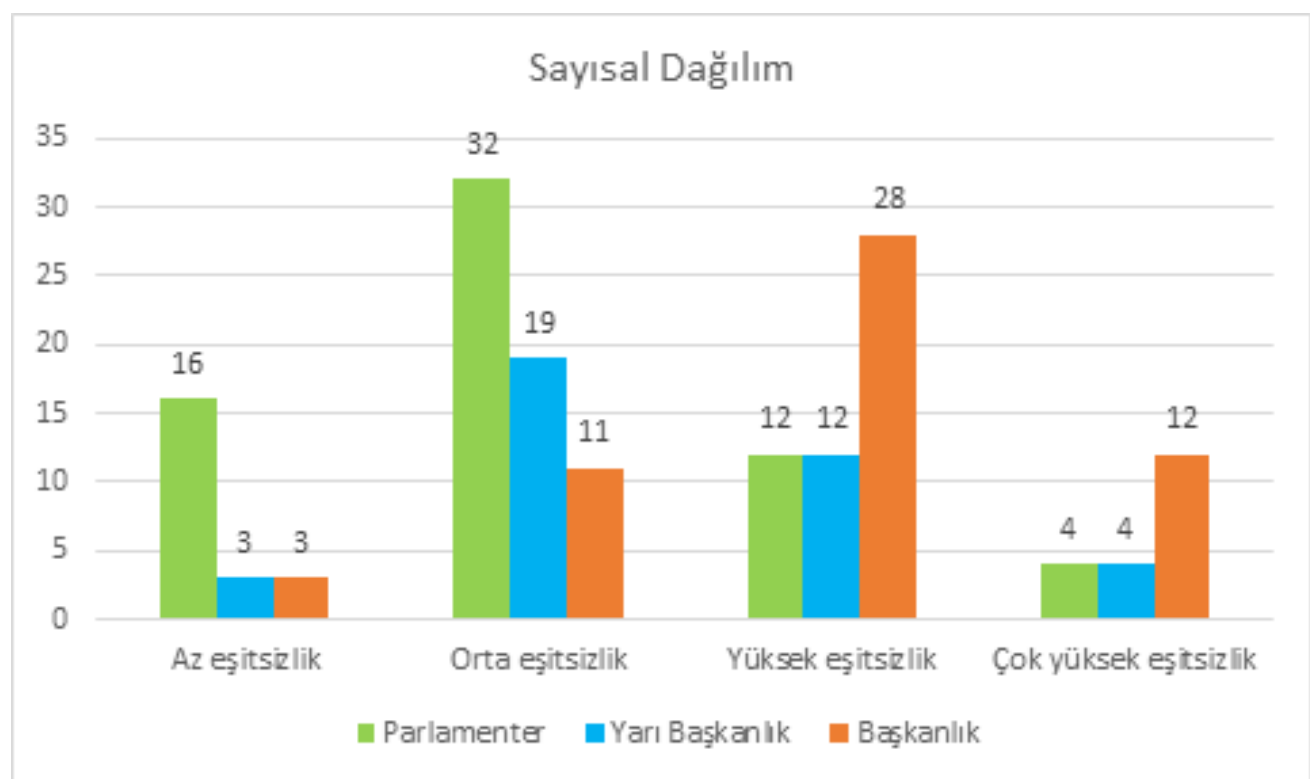

64 parlamenter ülkenin ağırlıklı kısmı (48 ülke) gelir dağılımı bakımından az veya orta eşitsizlik seviyesinde bulunurken, 54 başkanlık ülkesinin büyük kısmı (40 ülke) gelir dağılımında yüksek veya çok yüksek eşitsizlik seviyesinde yer almaktadır.

\section{b) 75 Ülkede Gelir Dağılımı Eşitsizliği}

Tablo 2'de gelir dağılımı eşitliği konusunda her üç yönetim sisteminin en az eşitsizliğe sahip ilk 25 ülkesine ait veriler yer alıyor. 161 ülke arasında dünya ortalaması 39,32 iken tabakalı olarak seçilen 75 ülkenin gelir dağılımı eşitliği endeks ortalaması 33,40 olmaktadir.

Tablo 2. 75 Ülkede Gelir Dağglımı Eşitsizliği: Yönetim Sistemlerine Göre Ülke Ortalamaları

\begin{tabular}{|c|c|c|c|c|c|c|c|c|}
\hline Yönetim sistemi & 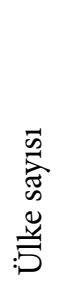 & 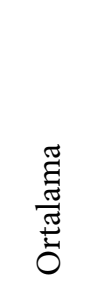 & 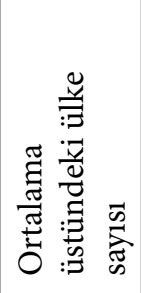 & 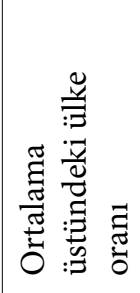 & 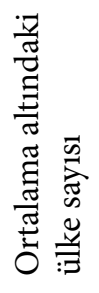 & 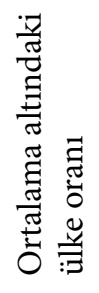 & 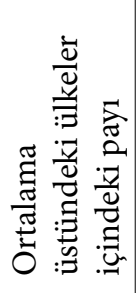 & 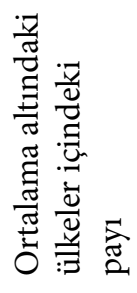 \\
\hline Parlamenter & 25 & 28,90 & 25 & 100 & 0 & 0 & 60,98 & 0 \\
\hline Yarı Başkanlık & 25 & 34,38 & 11 & 44 & 14 & 56 & 26,83 & 41,18 \\
\hline Başkanlık & 25 & 36,91 & 5 & 20 & 20 & 80 & 12,20 & 58,82 \\
\hline 75 Ülke & 75 & 33,40 & 41 & & 34 & & 100 & 100 \\
\hline
\end{tabular}

Parlamenter ülkeler 28,90 ortalama ile 33,40 olan 75 ülke ortalamasının üzerinde yer alıyor. Yarı başkanlık sistemi ile yönetilen ülkeler 34,38 ortalama ile dünya ortalama- 
sının altında kalıyor. Başkanlık sistemiyle yönetilen ülkeler ise yüzde 36,91 ortalama ile yarı başkanlık sisteminin de altında bulunuyor. 75 ülke içinde ortalama üstündeki 41 ülkenin 25'ini parlamenter ülkeler, 11'ini yarı başkanlık sistemiyle yönetilen ülkeler ve 5 'ini başkanlık sistemiyle yönetilen ülkeler oluşturuyor.

Grafik 7. 75 Ülkede Gelir Dağılımı Eşitsizliği: Yönetim Sistemlerine Göre Ülke Ortalamaları

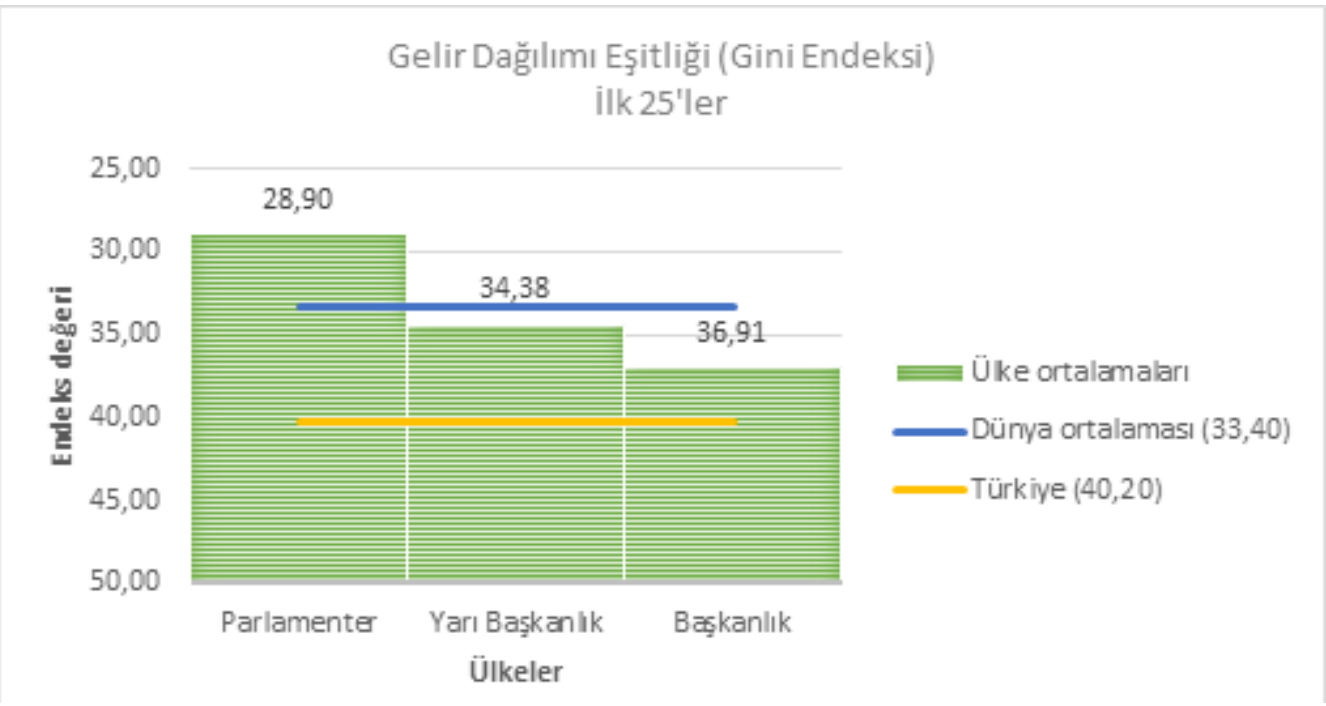

Gelir dağılımı eşitliğinde 75 ülke ile karşılaştırıldığında, Türkiye 40,2'lik puan ile hem dünya ortalamasının hem de üç yönetim sisteminin her birinin ortalamasının altında kalıyor. Bu sonuçla Türkiye gelir dağlımı eşitliğinde dünyada 89 . sırada bulunuyor.

Grafik 8. 75 Ülkede Gelir Dağılımı Eşitsizliği: Yönetim Sistemlerine Göre Ortalama Üstündeki Ülkelerin Oranı

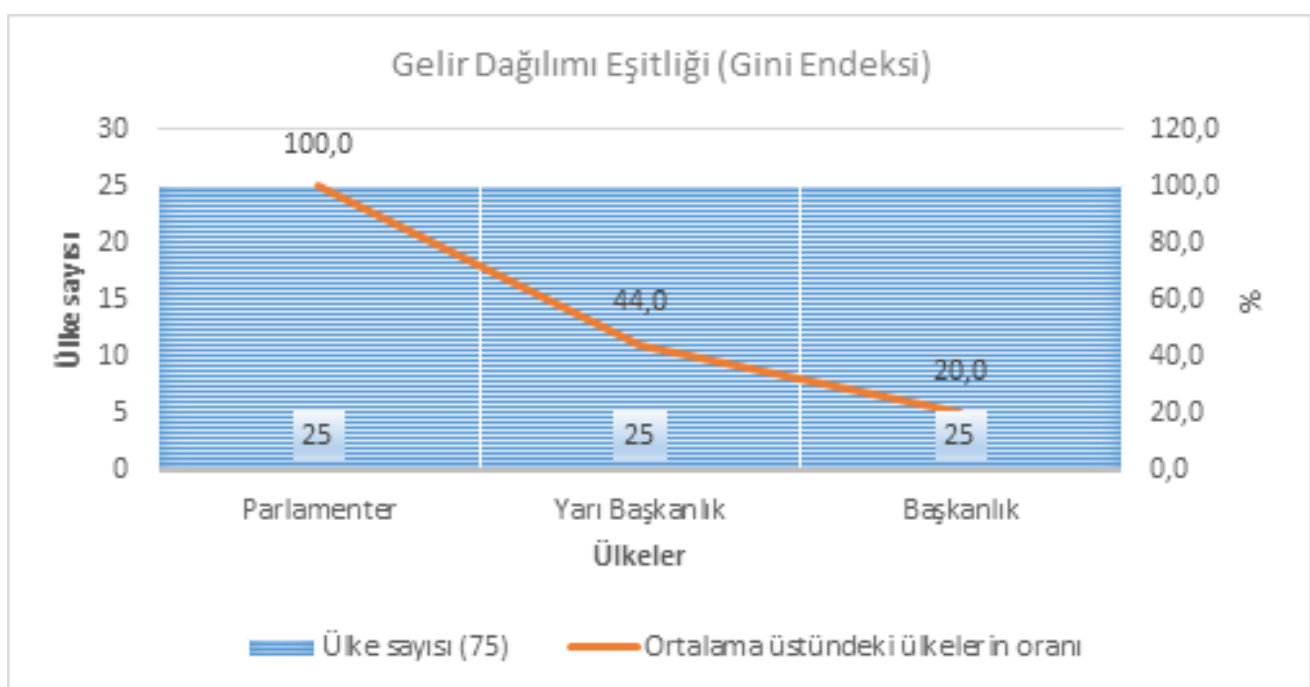

75 ülke arasında, parlamenter sistemle yönetilen ülkelerin tümü, yarı başkanlık ile yönetilenlerin yüzde 44 'ü ve başkanlık sistemiyle yönetilen ülkelerin yüzde 20 'si Gini Endeksinnde dünya ortalamasının üzerindedir. 
Grafik 9. 75 Ülkede Gelir Dağılımı Eşitsizliği: Yönetim Sistemlerinin Ortalama Üstündeki Ülkeler İçindeki Payı

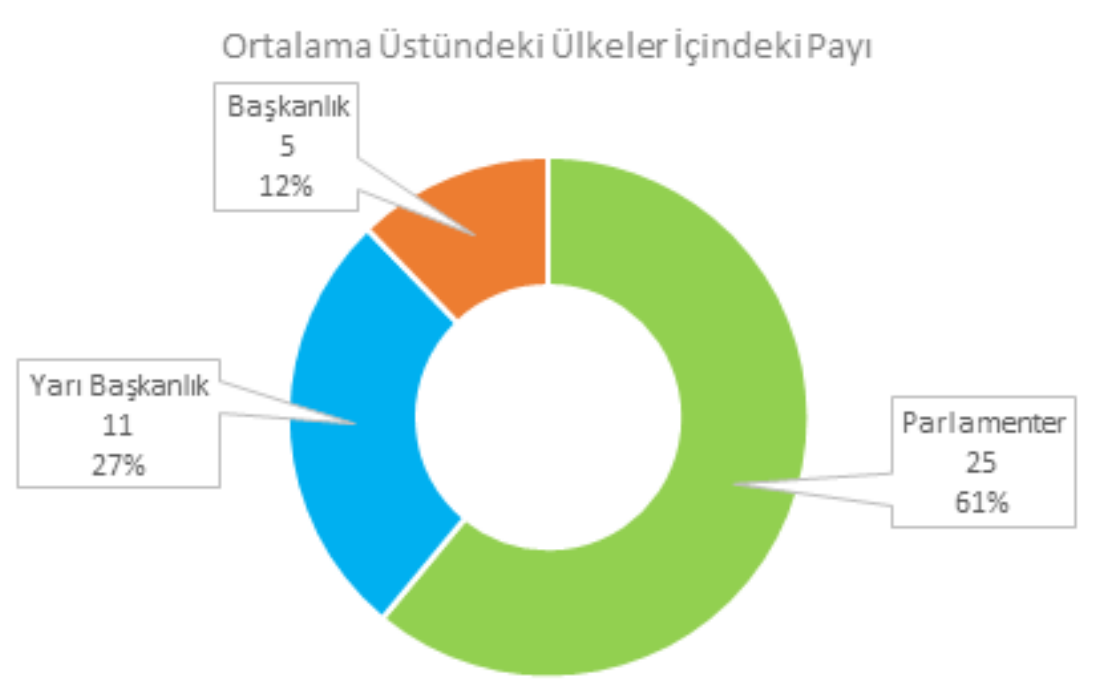

Grafik 10. 75 Ülkede Gelir Dağılımı Eşitsizliği: Yönetim Sistemlerinin Ortalama Altındaki Ülkeler İçindeki Payı

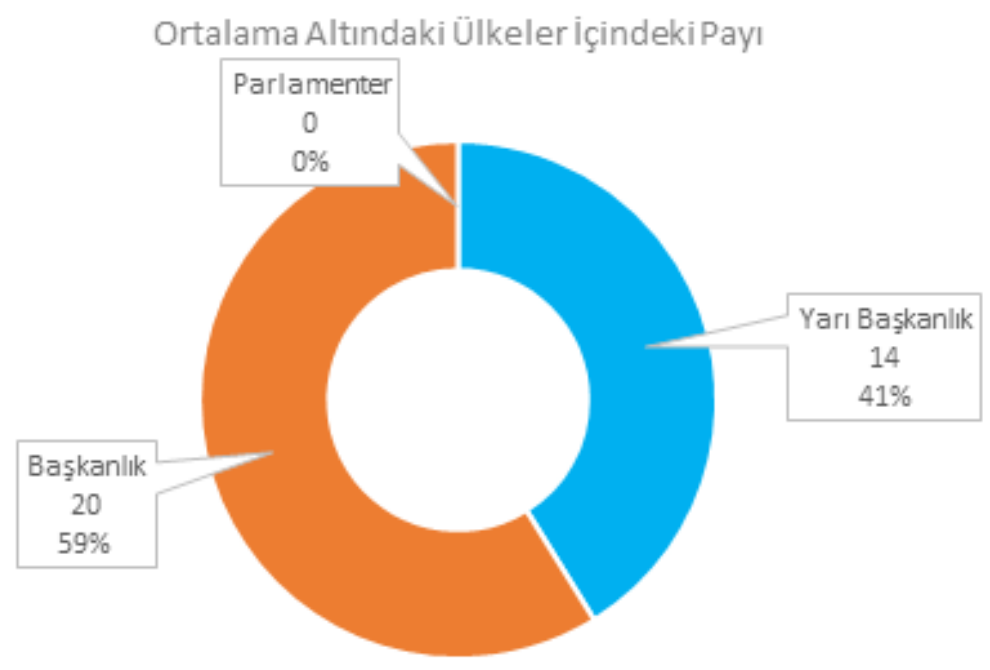

Gelir dağılımı eşitliğinde, ortalama üstündeki ülkeler arasında parlamenter sistemin payı yüzde 61, yarı başkanlık sisteminin yüzde 27 ve başkanlık sisteminin yüzde 12 'dir. Ortalama altında parlamenter ülke bulunmamaktadır. Öte yandan ortalama altındaki ülkelerin yüzde 59'unu başkanlık sistemiyle yönetilen ülkeler oluşturmaktadir.

\section{Yönetim Sistemlerine Göre Ülkelerin Yoksulluk Durumu}

Çok Boyutlu Küresel Yoksulluk Endeksi (MPI) aşırı boyutlardaki küresel yoksulluğu ölçmek üzere Oxford Yoksulluk ve İnsani Gelişme Girişimi (Oxford Poverty and 
Human Development Initiative - OPHI) ile Birleşmiş Milletler Kalkınma Programı İnsani Gelişme Raporu tarafından hazırlanmaktadır.

Endekste, yoksulluk üç boyutta ele alınmaktadır: Eğitim, sağlık ve hayat standardı. Eğitim boyutunda eğitim yılı ve çocukların okula devamı; sağlık boyutunda çocuk ölümleri ve beslenme; hayat standardı boyutunda ise elektrik kullanımı, sağlık, içme suyu, barınma, kullanılan yakıt türü ve sahip olunan araç gereçler yer alıyor ${ }^{31} .2015$ Endeksi’nde küresel ölçekte en yoksul durumda değerlendirilen 101 ülke bulunmaktadir.

Grafik 11. Dünyada Yoksulluk: Yönetim Sistemlerine Göre Yoksul ve Yoksul Olmayan Ülkelerin Dă̆ılımı (Yüzde)

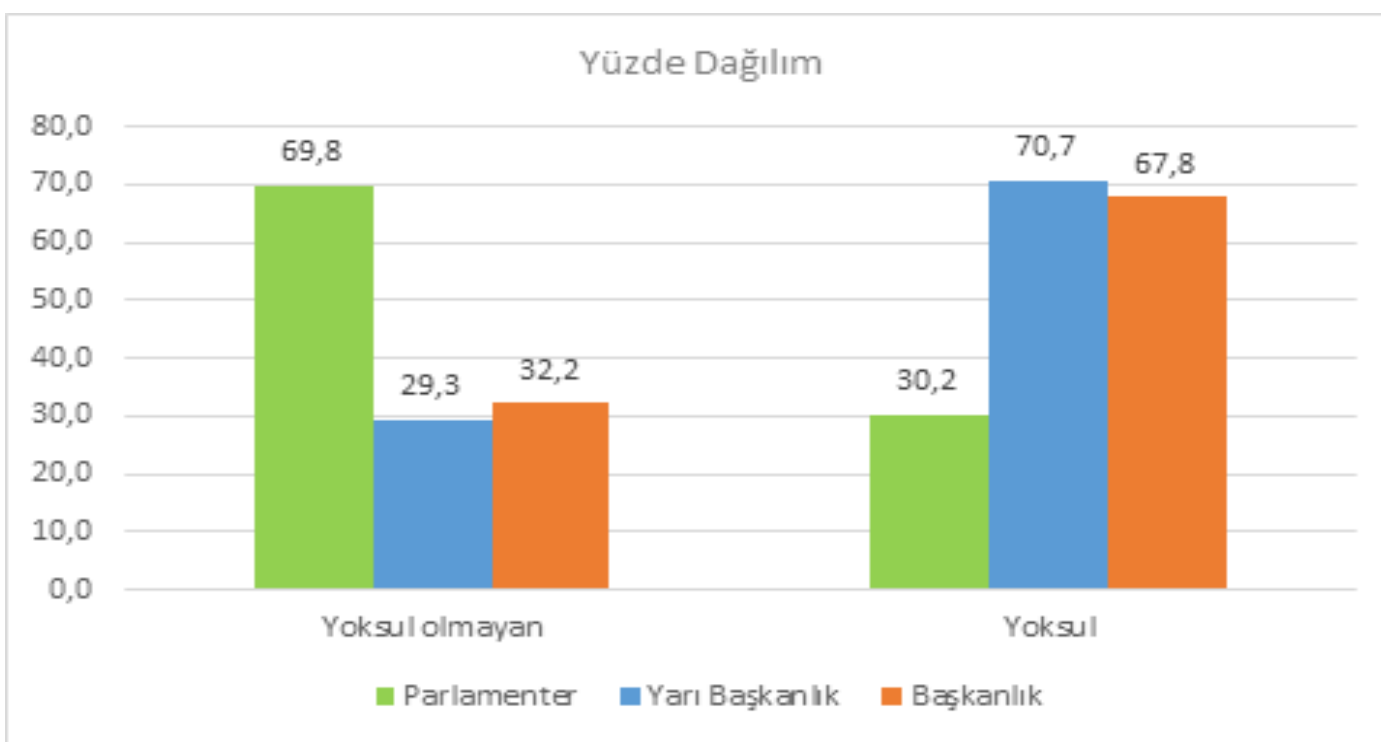

BM'ye üye 193 ülke arasında 86 parlamenter ülkenin 60'ı yoksul olmayan ülke grubunda yer alıyor. Başkanlık sistemiyle yönetilen 59 ülkenin 19’u; yarı başkanlıkla yönetilen 41 ülkenin 12'si yoksul olmayan ülke grubunda. Diğer yandan, parlamenter ülkelerin 26’sı (\%30,2); başkanlıkla yönetilen ülkelerin 40’1 $(\% 67,8)$ ve yarı başkanlıkla yönetilen ülkelerin 29'u (\%70,7’si) yoksul 101 ülke arasında yer alıyor. Parlamenter ülkelerin 1/3'ünden azı yoksul gruptayken, başkanlık ve yarı başkanlıkla yönetilen ülkelerin 2/3'ünden fazlası yoksulluk içinde bulunuyor.

\section{a) 101 Ülkede Yoksulluk}

Yoksul ülkelerin Çok Boyutlu Küresel Yoksulluk Endeksi’ne ilişkin değerleri ve bu ülkelerin yönetim sistemlerine göre dağılımı makalenin sonunda Tablo 6'da yer alıyor. Tabloda ayrıca “yoksulların nüfus içindeki oranı” ve "yoksullar arasındaki mahrumiyet yoğunluğu” da verilmektedir. Ülkelerin sıralamasında Oxford Yoksulluk ve

31 Sabina Alkire ve Gisela Robles, Multidimensional Poverty Index - 2015: Brief Methodological Note and Results, Oxford Poverty and Human Development Initiative, University of Oxford, Briefing 31, 2015, s. 4-5. Endeks verileri için: "Global MPI Data Tables for 2015: Table 1.1 Main MPI Results”, Oxford Poverty and Human Development Initiative, http://www.ophi.org.uk/multidimensional-poverty-index/mpi-2015/mpi-data, (Erişim: 14 Ocak 2016). 
İnsani Gelişme Girişimi’nin Yoksulluk Endeksi'ne göre, en az yoksuldan en çok yoksula doğru 0 ile 1 değerleri arasında yapmış olduğu ülke sıralaması dikkate alınmış, bu değerler yönetim sistemlerine göre düzenlenmiştir. Tablo 3'te ise yoksul ülkelerin yönetim sistemlerine göre bilgileri, ortalama endeks değerleri, ortalama altında ve üstünde kalan ülke sayıları ile oranları yer almaktadır.

Tablo 3. Dünyada Yoksulluk: Yönetim Sistemlerine Göre Sonuçlar (101 Ülke)

\begin{tabular}{|c|c|c|c|c|c|c|c|c|}
\hline Yönetim sistemi & 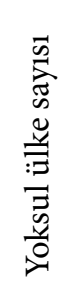 & 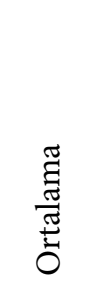 & 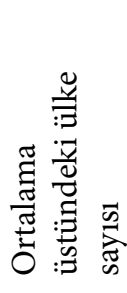 & 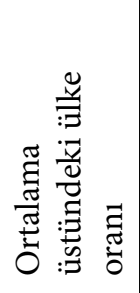 & 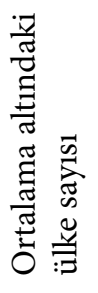 & 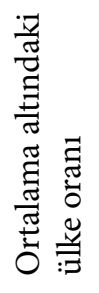 & 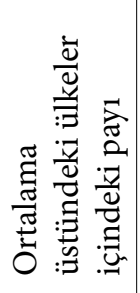 & 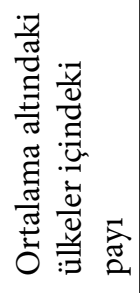 \\
\hline Parlamenter & 26 & 0,094 & 20 & 76,92 & 6 & 23,08 & 35,09 & 13,64 \\
\hline Yarı Başkanlık & 29 & 0,207 & 14 & 48,28 & 15 & 51,72 & 24,56 & 34,09 \\
\hline Başkanlık & 40 & 0,198 & 20 & 50 & 20 & 50 & 35,09 & 45,45 \\
\hline Diğer & 6 & 0,180 & 3 & 50 & 3 & 50 & 5,26 & 6,82 \\
\hline Dünya & 101 & 0,172 & 57 & & 44 & & 100 & 100 \\
\hline
\end{tabular}

Yoksulluk endeksinde değer ne kadar küçük ise, ülke o kadar az yoksul, değer ne kadar yüksekse o kadar çok yoksul durumda değerlendirilmektedir. Endekste yer alan parlamenter ülkeler 0,094 ortalama ile dünya yoksulluk ortalamasının üzerinde bulunuyor; diğer bir ifadeyle parlamenter ülkeler en az yoksulluk ortalamasına sahiptir. Başkanlık ve yarı başkanlık sistemi ile yönetilen ülkeler ise 0,198 ve 0,207 ortalama değerler ile 0,172 olan dünya yoksulluk ortalamasının oldukça altında kalmaktadır.

Grafik 12. Dünyada Yoksulluk: Yönetim Sistemlerine Göre Yoksul Ülkelerin Ortalamaları

Küresel Yoksulluk Endeksi 2015

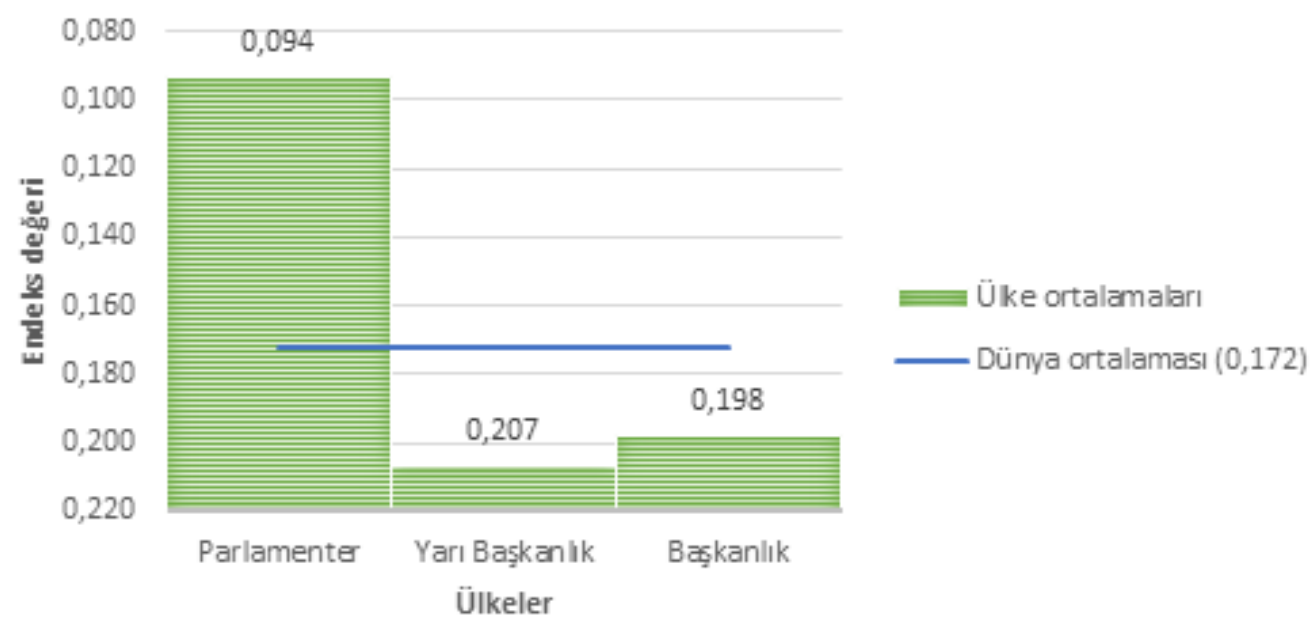


Grafikte görüldüğü üzere, yoksulluk yarı başkanlık ve başkanlık sistemiyle yönetilen ülkelerde daha yaygın durumda. Parlamenter ülkelerin yoksul ülkeleri dünya ortalamasının ve diğer iki sitemin ortalamalarının hayli üstünde bir seviyede bulunuyor.

Grafik 13. Dünyada Yoksulluk: Yönetim Sistemlerine Göre Ortalama Üstündeki Ülkelerin Oranı

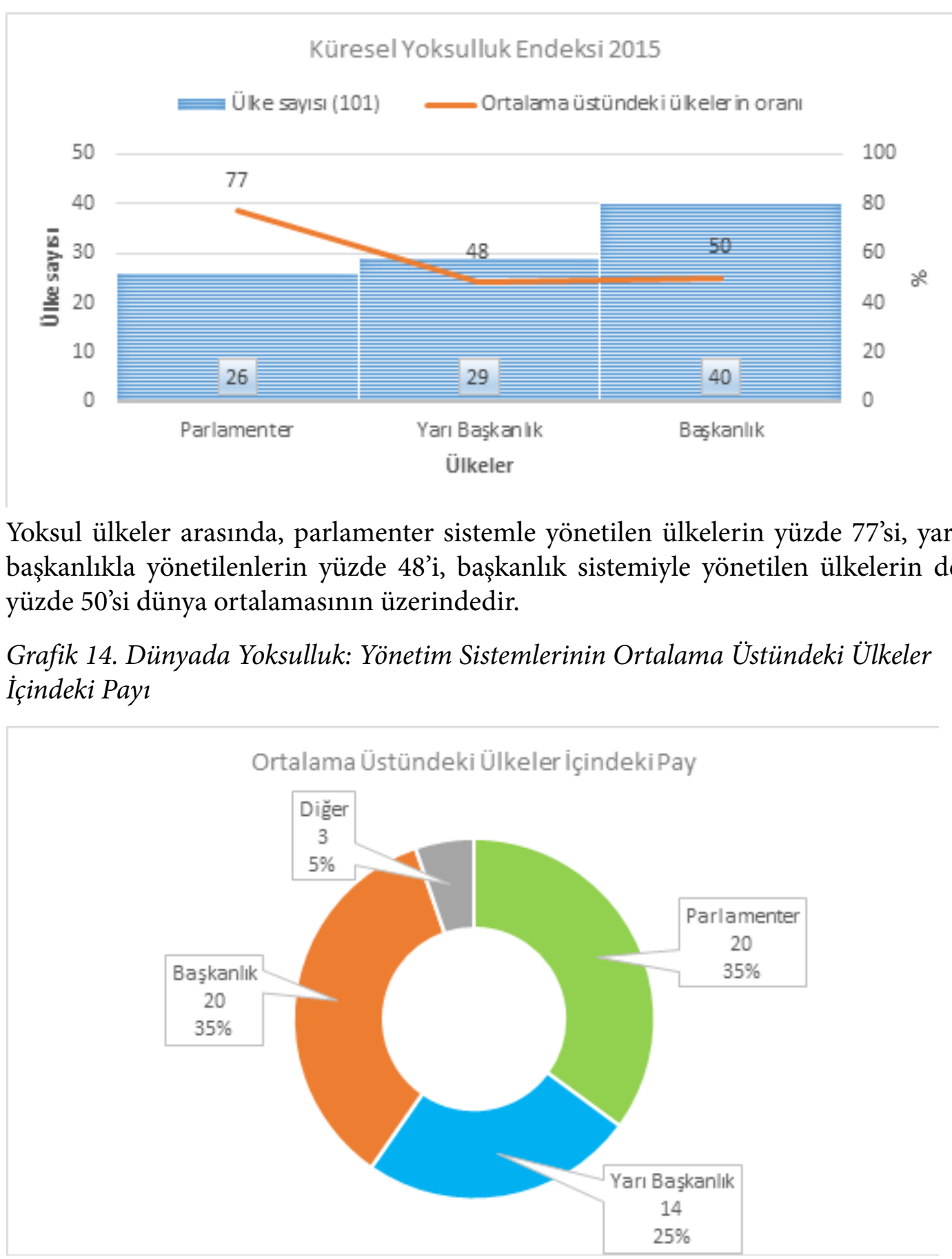


Grafik 15. Dünyada Yoksulluk: Yönetim Sistemlerinin Ortalama Altındaki Ülkeler İçindeki Payı

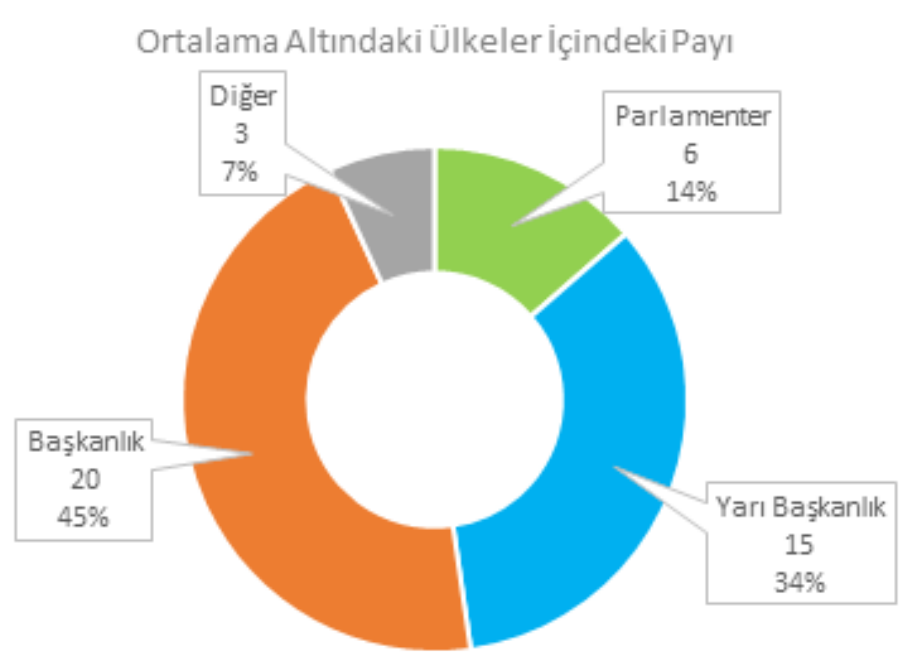

Ortalama üstündeki ülkeler içinde parlamenter ve başkanlık sistemlerinin her birinin payı yüzde 35'tir. Ancak, dünya ortalamasının altındaki ülkelerde parlamenter sistemin payı yüzde 14 , başkanlık sisteminin payı ise yüzde 45 'tir. Bu da, başkanlık ve yarı başkanlık sistemiyle yönetilen ülkelerin dünyadaki yoksulluğun çok büyük bir kısmını paylaştığını gösteriyor.

Yoksul ülkelerin durumunu değerlendirirken Grafik 11'de yer alan yoksul olan ve olmayan ülke oranlarını göz önünde bulundurmak gerekir. Ayrıca yoksul ülke kategorisinde kaç ülke bulunduğu kadar, en azdan en çoğa doğru 7 seviyeli yoksulluk ölçeğinde bu ülkelerin nasıl dağıldığı da önemlidir.

Grafik 16. Dünyada Yoksulluk: Yönetim Sistemlerine Göre Yoksul Ülkelerin Dağılımı ve Yoksulluk Seviyesi

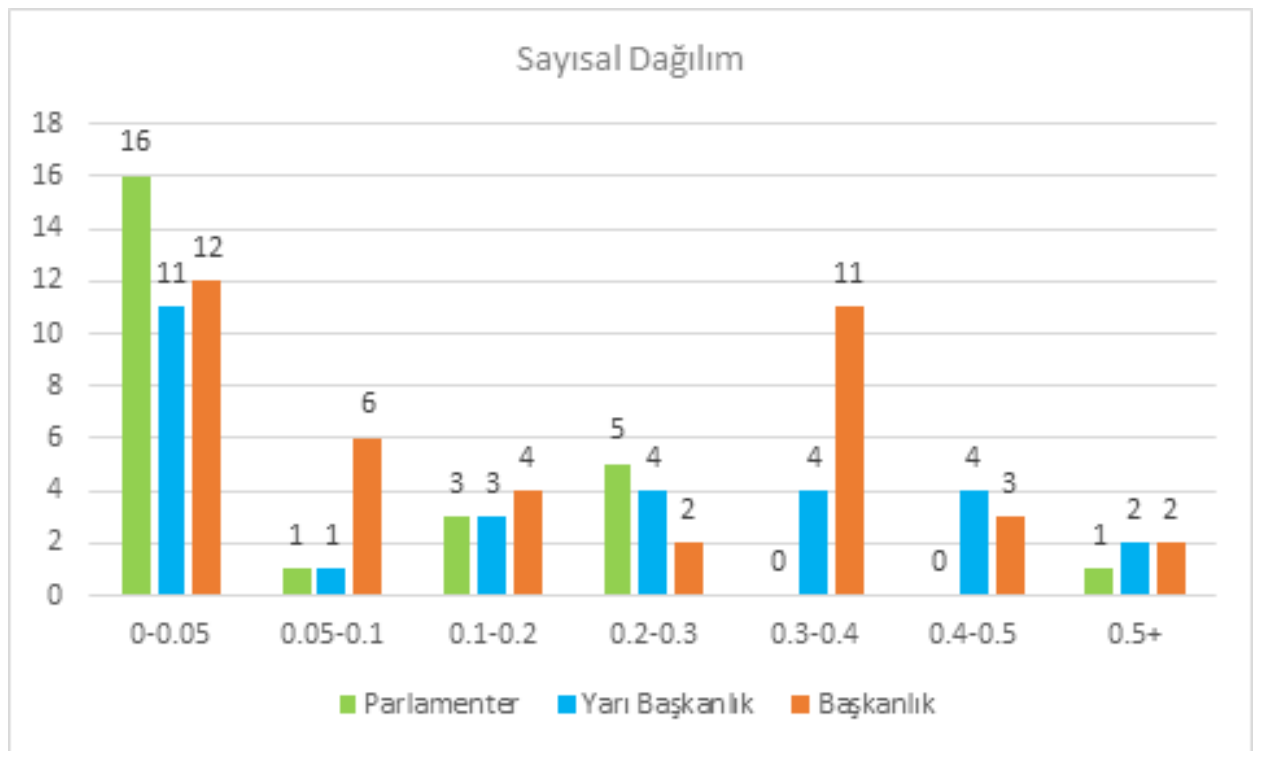


26 yoksul parlamenter ülkenin 16'sı en az yoksulluk seviyesinde, 10'u ise diğer seviyelerdedir. 40 başkanlık ülkesinin ise 12'si en az yoksulluk seviyesinde, 28'i ise diğer seviyelerdedir.

\section{b) 75 Ülkede Yoksulluk}

Tablo 4’te Küresel Yoksulluk Endeksi'nde her üç yönetim sisteminin en yoksul 25 ülkesine ait veriler yer almaktadır. 75 ülkenin 2015 Yoksulluk Endeksi ortalaması 0,213'tür.

Tablo 4. 75 Ülkede Yoksulluk: Yönetim Sistemlerine Göre Sonuçlar

\begin{tabular}{|c|c|c|c|c|c|c|c|c|}
\hline Yönetim sistemi & 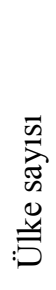 & 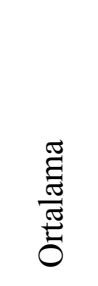 & 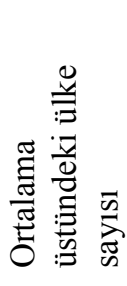 & 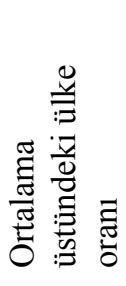 & 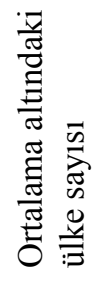 & 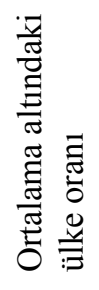 & 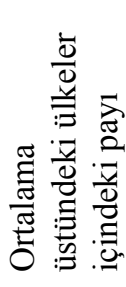 & 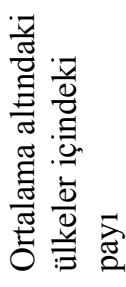 \\
\hline Parlamenter & 25 & 0,097 & 20 & 80 & 5 & 20 & 52,63 & 13,51 \\
\hline Yarı Başkanlık & 25 & 0,239 & 11 & 44 & 14 & 56 & 28,95 & 37,84 \\
\hline Başkanlık & 25 & 0,303 & 7 & 28 & 18 & 72 & 18,42 & 48,65 \\
\hline 75 Ülke & 75 & 0,213 & 38 & & 37 & & 100 & 100 \\
\hline
\end{tabular}

75 ülke içinde en yoksul parlamenter ülkeler 0,097 ortalama ile 0,213 olan dünya ortalamasının üzerinde bulunuyor. Yarı başkanlık sistemi ile yönetilen ülkeler 0,239 ortalama ile dünya ortalamasının altında, başkanlık sistemiyle yönetilen ülkeler ise 0,303 ortalama ile yarı başkanlık sisteminin de altında kalıyor. 75 ülke içinde ortalama üstündeki 38 ülkenin 20'sini parlamenter ülkeler, 11'ini yarı başkanlık sistemiyle yönetilen ülkeler ve 7'sini başkanlık sistemiyle yönetilen ülkeler oluşturuyor.

Grafik 17. 75 Ülkede Yoksulluk: Yönetim Sistemlerine Göre Yoksul Ülkelerin Ortalamaları

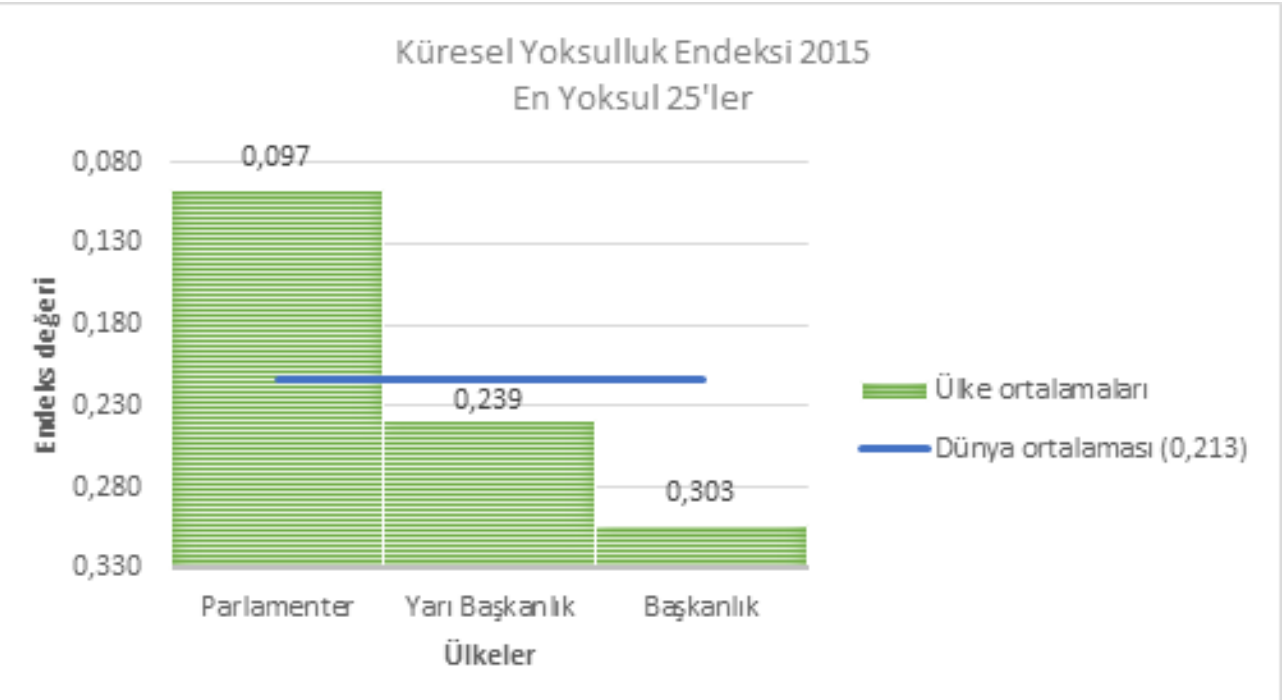


Grafik 18. 75 Ülkede Yoksulluk: Yönetim Sistemlerine Göre Ortalama Üstündeki Ülkelerin Oranı

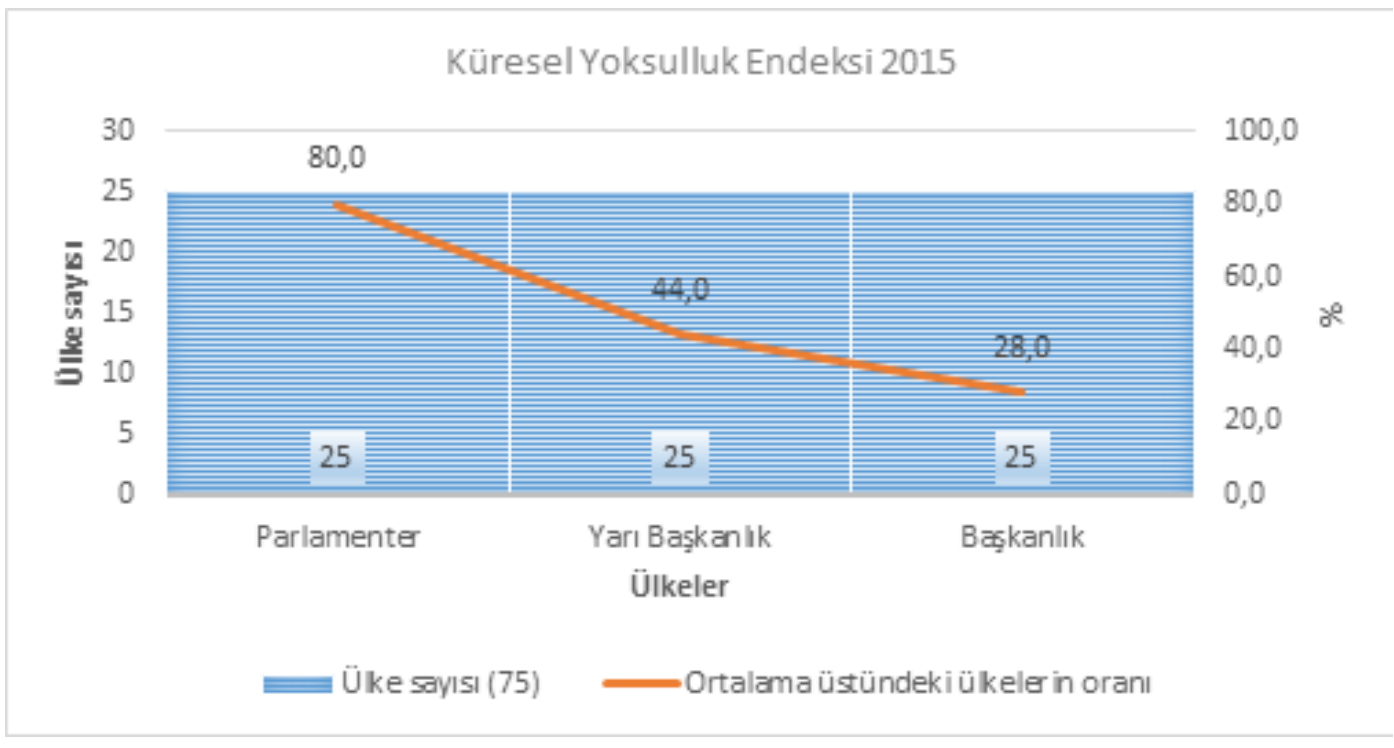

75 ülke içinde parlamenter ülkelerin yüzde 80 'i, yarı başkanlık ülkelerinin yüzde 44 'ü ve başkanlık sistemi ile yönetilen ülkelerin yüzde 28'i dünya ortalamasının üzerindedir.

Grafik 19. 75 Ülkede Yoksulluk: Yönetim Sistemlerinin Ortalama Üstündeki Ülkeler Içindeki Payı

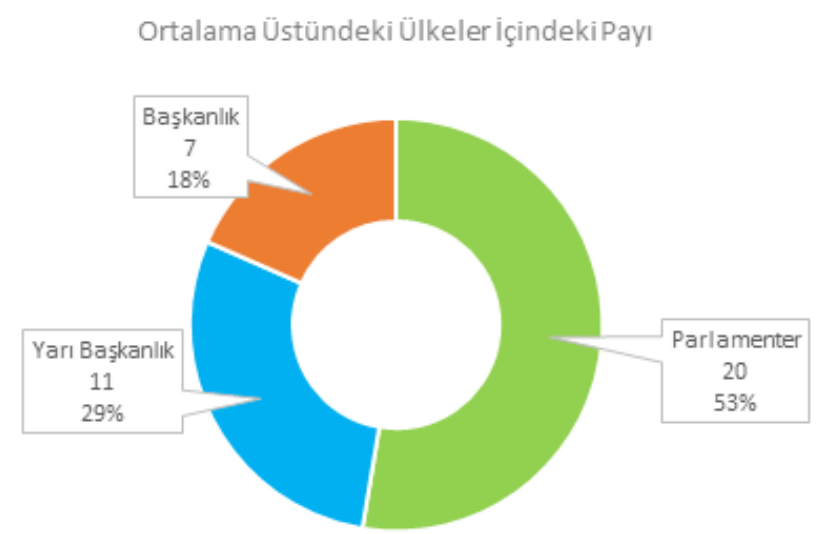

En yoksul 75 ülke arasında, dünya ortalamasının üstündeki ülkeler arasında parlamenter sistemin payı yüzde 53, yarı başkanlık sisteminin yüzde 29 ve başkanlık sisteminin yüzde 18 'dir. 
Grafik 20. 75 Ülkede Yoksulluk: Yönetim Sistemlerinin Ortalama Altındaki Ülkeler Içindeki Payı

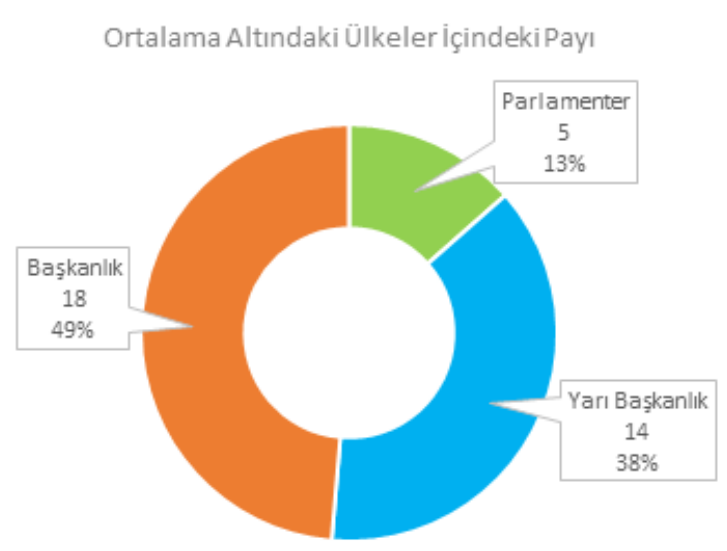

Dünya ortalamasının altında kalan ülkeler içinde ise parlamenter sistemin payı yüzde 13 'ken, yarı başkanlık sisteminin payı yüzde 38 ve başkanlık sisteminin payı yüzde 49'dur.

\section{Sonuç ve Değerlendirmeler}

$\mathrm{Bu}$ makalede incelenen gelir dağılımı eşitliği/eşitsizliği (Gini endeksi) ve yoksulluk endeksi sonuçları yönetim sistemlerinin durumunu sarih bir şekilde ortaya koymaktadır. Gelir dağılımı eşitsizliği açısından endekste yer alan 161 ülke içinde parlamenter ülkeler 35,73 ortalama ile 39,32 olan dünya ortalamasının üstünde bulunmaktadır; bu sonuca göre parlamenter ülkeler en az gelir dağılımı eşitsizliği ortalamasına sahip bulunuyor. Yarı başkanlık ülkeleri 39 ortalama değer ile dünya ortalamasına yakın bir noktada. Fakat başkanlık sistemi ile yönetilen ülkeler 43,63 ortalama değer ile dünya ortalamasının altında kalmaktadır.

Grafik 21. Dünyada Gelir Dă̆ılımı Eşitsizliği: Yönetim Sistemlerine Göre Ülkelerin Dağılımı ve Eşitsizlik Seviyesi (Yüzde)

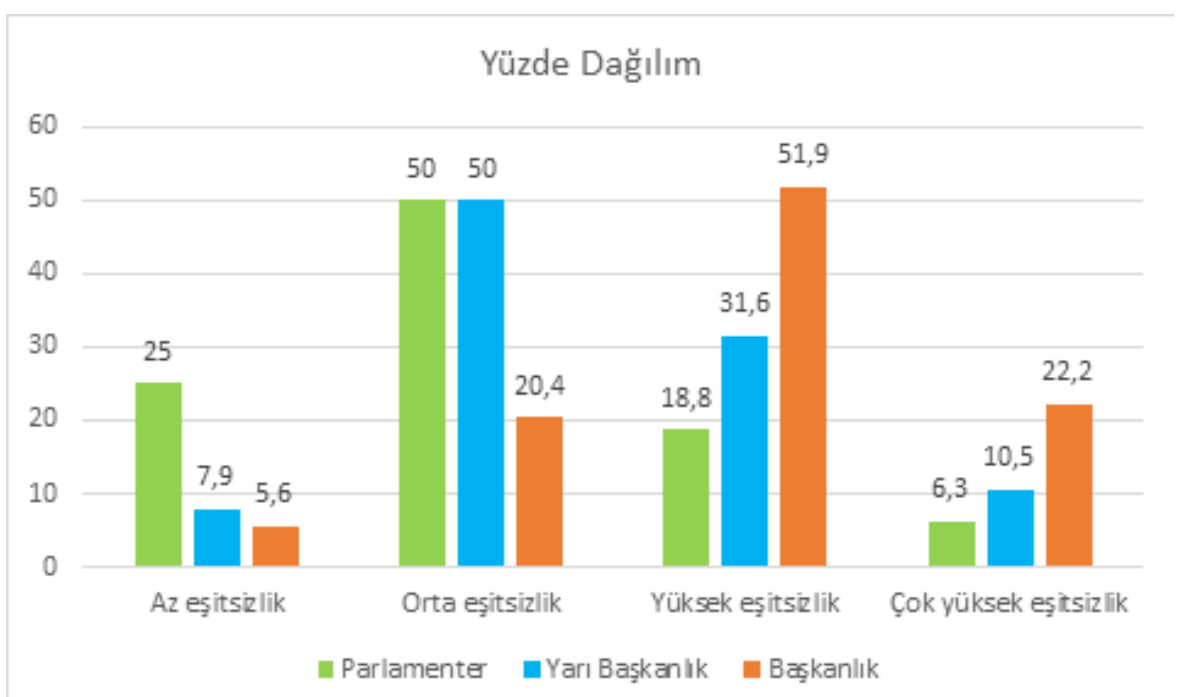


Parlamenter ülkelerin yüzde 25’i az, yüzde 50'si orta, yüzde 6’sı çok yüksek gelir dağılımı eşitsizliği seviyesindedir. Başkanlık ülkelerinin ise yüzde 6’sı az, yüzde 74’ü yüksek ve çok yüksek gelir dağılımı eşitsizliği seviyesindedir. Yarı başkanlık sisteminde de gelir dağılımı eşitsizliği yüksek olmakla birlikte, yönetim sistemleri içinde gelir dağılımı eşitsizliği en yoğun olarak başkanlık sistemiyle yönetilen ülkelerde yaşanmaktadır.

Yoksulluk durumunda da benzer bir tablo karşımıza çıkmaktadır. Parlamenter ülkelerin yüzde 30'u, başkanlık ülkelerinin yüzde 68'i ve yarı başkanlık ülkelerinin yüzde 71'i yoksul 101 ülke arasında yer almaktadır. Buna göre parlamenter ülkelerin 1/3'ünden azı yoksul gruptayken, başkanlık ve yarı başkanlık ülkelerinin 2/3'ünden fazlası yoksulluk içinde bulunuyor. Yoksul ülkelerin içinde bulunduğu yoksulluk seviyesine göre dağılımı da yönetimlerin işleyişine dair hayli fikir vermektedir.

Grafik 22. Dünyada Yoksulluk: Yönetim Sistemlerine Göre Yoksul Ülkelerin Dağılımı (Yüzde)

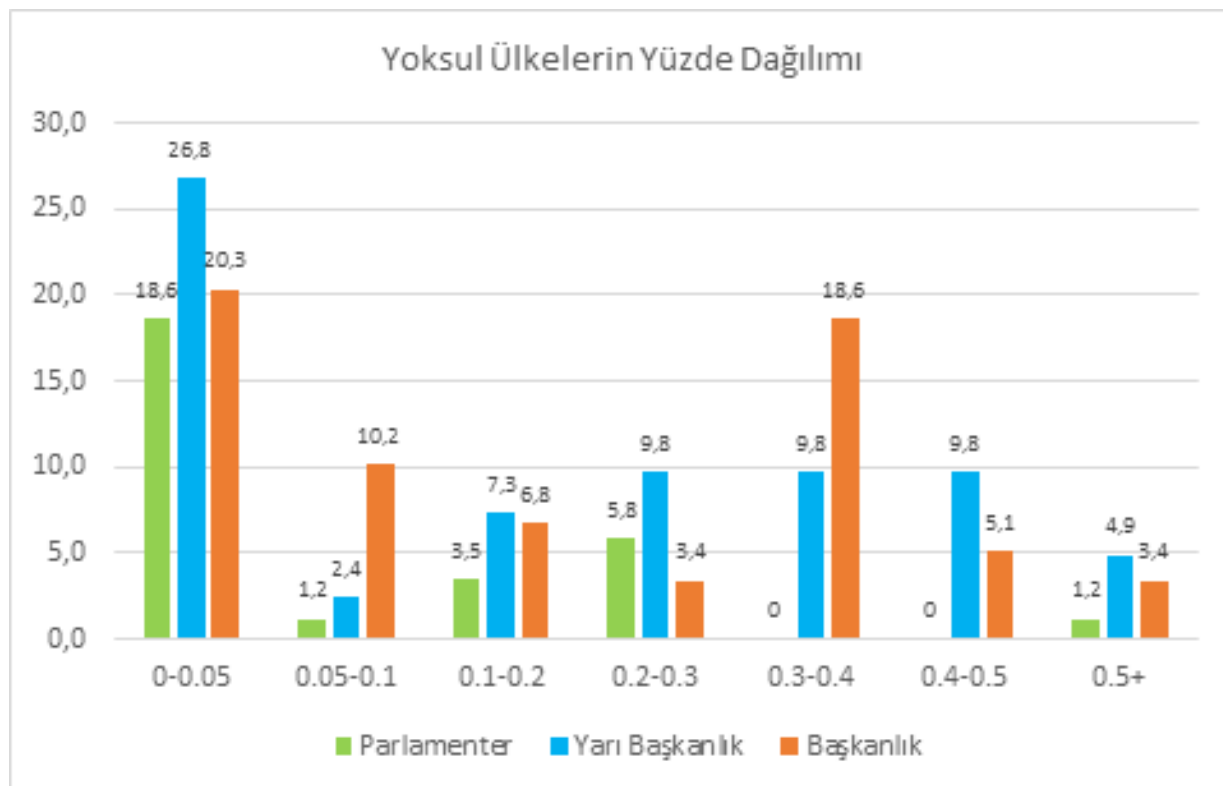

Üstteki grafiğe göre, 86 parlamenter ülkenin yüzde 19'unun en az yoksulluk düzeyinde bulunduğu görülmektedir. 59 başkanlık ülkesinin ise yüzde 20'sinin en az yoksulluk seviyesinde, yüzde 48'inin ise daha yüksek yoksulluk seviyelerinde olduğu tespit edilebiliyor. Başkanlık ve yarı başkanlık ülkelerinin gelir dağılımı eşitsizliğinde olduğu gibi, yoksullukta da parlamenter ülkelerden ciddi biçimde farklı bir seyir izlediği görülüyor.

Çalışmanın sonuçları göstermektedir ki, gelir dağılımının görece adaletli olduğu ve refahın tüm topluma görece dengeli biçimde dağıtıldığı ülkeler ağırlıklı olarak parlamenter sistem ile yönetilmektedir.

Bu makalede ortaya çıkan sonuçları ekonomik gelişmişlik, hukuk, sağlık hizmetleri, yaşam standartları, demokrasi, basın özgürlüğ̈̈, siyasi haklar ve özgürlükler, istikrar gibi yine uluslararası düzeyde ölçümü yapılan endekslerle birlikte değerlendirmek yönetim sistemlerine dair daha fazla fikir verecektir. Kaldı ki, bu çalışmada yer alan 
parlamenter, başkanlık ve yarı başkanlık ülkelerinin listesine göz atmak ve ülkelerle ilgili kısa bir araştırma yapmak dahi yönetim sistemlerinin işleyişine ve muhtemel sonuçlarına dair bir fikir verecektir.

\section{Kaynakça}

“2015 World Development Indicators: Distribution of Income or Consumption”, The World Bank, http://wdi.worldbank.org/table/2.9, Son Güncelleme: 16.12.2015. (Erişim: 26 Ocak 2016).

Alkire, Sabina ve Gisela Robles, Multidimensional Poverty Index - 2015: Brief Methodological Note and Results, Oxford Poverty and Human Development Initiative, University of Oxford, Briefing 31, 2015

"Angola Country Profile", BBC News, http://www.bbc.com/news/worldafrica-13036732, 11 Ocak 2016, (Erişim: 2 Şubat 2016).

"Angola", Freedom House, https://freedomhouse.org/report/freedom-world/2015/ angola, (Erişim: 2 Şubat 2016).

Bağce, H. Emre, Parlamenter Sistem mi, Başkanlık mı?: Yoksulluktan Hukukun Üstünlüğ̈̈ne Ülkelerin Dünyadaki Yeri, İstanbul: Gonca Yayınevi, 2016.

Bağce, H. Emre, "Parlamenter ve Başkanlık Sistemiyle Yönetilen Ülkelerde İstikrar Durumu”, Köprü Dergisi 136 (2016): 23-36.

Bağce, H. Emre, “The Role of Political Institutions in Tackling Political Fragmentation and Polarization: Presidentialism versus Parliamentarism", C. Ü. İktisadi ve İdari Bilimler Dergisi 3/1 (2002): 147-162, Çevrimiçi: http://www.emrebagce.com/ yayinlar/The-role-of-political-institutions-in-tackling-political-fragmentationand-polarization.pdf.

Barrington, Lowell, Comparative Politics: Structures and Choices, 2. Bask1, Wadsworth: Cengage Learning, 2012.

Clark, William Roberts, Matt Golder, Sona Nadenichek Golder, Principles of Comparative Politics, 2. Bask1, Los Angeles, London, New York: Sage Publications, 2013.

"Côte D'ivoire: Public Administration Country Profile", United Nations Division for Public Administration and Development Management (DPADM), Department of Economic and Social Affairs (DESA), September 2007, Çevrimiçi: http:// unpan1.un.org/intradoc/groups/public/documents/un/unpan028168.pdf, (Erişim: 2 Şubat 2016).

"Distribution of Family Income - Gini Index", CIA The World Factbook, https://www. cia.gov/library/publications/the-world-factbook/fields/2172.html, (Erişim: 5 Şubat 2016).

“Djibouti: Government”, Global Edge, Michigan State University, http://globaledge. msu.edu/countries/djibouti/government, (Erişim: 4 Şubat 2016).

Elgie, Robert, "What is Semi-Presidentialism and Where is It Found?", Robert Elgie ve Sophia Moestrup (ed.), Semi-Presidentialism Outside Europe: A Comparative Study, London, New York: Routledge, 2007. 
"Executive Branch", Government of Namibia, http://www.gov.na/executive, (Erişim: 6 Şubat 2016).

"Executive Branch", Government of the Federated States of Micronesia, http://www. fsmgov.org/ngovt.html, (Erişim: 3 Şubat 2016).

Gastwirth, Joseph L., "The Estimation of the Lorenz Curve and Gini Index", The Review of Economics and Statistics, 54/ 3 (1972): 306-316.

"General Information on the Political System of AR", Azerbaycan Respublikasının Ali Mahkemesi, http://www.supremecourt.gov.az/en/static/view/1, (Erişim: 2 Şubat 2016).

“Global MPI Data Tables for 2015: Table 1.1 Main MPI Results”, Oxford Poverty and Human Development Initiative, http://www.ophi.org.uk/multidimensionalpoverty-index/mpi-2015/mpi-data, (Erişim: 14 Ocak 2016).

"Government System", The Government of the Republic of Armenia, http://www. gov.am/en/gov-system, (Erişim: 6 Şubat 2016).

“Government: Overview”, Embassy of Angola Washington D.C., http://www.angola. org/index.php?page=overview, (Erişim: 2 Şubat 2016).

“Government”, Services du Premier Ministre du Cameroun, http://www.spm.gov. $\mathrm{cm} /$ en/government.html, (Erişim: 5 Şubat 2016).

"Government", The Government of the Republic of Nauru, http://www.naurugov.nr/ government.aspx, (Erişim: 4 Şubat 2016).

"Income Gini Coefficient", United Nations Development Programme, Human Development Reports, http://hdr.undp.org/es/content/income-gini-coefficient, (Erişim: 28 Ocak 2016).

"Information about the President's Office", The Government of the Republic of Nauru, http://www.naurugov.nr/government/the-president's-office.aspx, (Erişim: 4 Şubat 2016).

"Islamic Republic of Iran: An Islamic Popular System (13)", Iran English Radio, http://english.irib.ir/analysis/articles2/item/169658-islamic-republic-of-iran,an-islamic-popular-system-13, (Erişim: 2 Şubat 2016).

Korkmaz, Tuğrul, "Hükümet Sistemleri ve Türkiye Üzerine Bir Analiz", Akademik Hassasiyetler Dergisi 3/6 (2016): 43-57.

"Organisation Structure”, Parliament of Singapore, https://www.parliament.gov.sg/ organisation-structure, (Erişim: 3 Şubat 2016).

"Parline Database: Parliamentary Oversight Module", Inter-Parliamentary Union, http://www.ipu.org/parline-e/mod-oversight.asp, (Erişim: 18 Eylül 2016).

"Political System", Slovak Republic.Org, http://www.slovak-republic.org/politics, (Erişim: 5 Şubat 2016).

"Prime Ministry", The Hashemite Kingdom of Jordan: The Official Site of the Jordanian e-Government, http://www.jordan.gov.jo/wps/portal/!ut/p/b1/04_SjzQ0tjS1NLYwNNCP0I_KSyzLTE8syczPS8wB8aPM4sMsvS3CvN0NDSw83C0MPL0MjMx8zZ2MDVwN9YNT8_RzoxwVAdrPvkU!/? nameEntity=The\%20 Prime\%20Ministry, (Erişim: 3 Şubat 2016). 
Reilly, Benjamin, "Semi-presidential Democracy in East Asia", East Asia Forum: Economics, Politics and Public Policy in East Asia and the Pacific, http:// www.eastasiaforum.org/2008/11/08/semi-presidentialism-and-democraticdevelopment-in-east-asia-grows (Erişim: 2 Şubat 2016).

Sánchez, Roberto Gándara, "Parliamentary and Presidential Systems", Puerto Rico Encyclopedia, http://www.enciclopediapr.org/ing/article.cfm?ref=13010903, 11 Eylül 2014 (Erişim: 2 Şubat 2016).

Shugart, Matthew Søberg, "Semi-Presidential Systems: Dual Executive And Mixed Authority Patterns", French Politics, 2005, no. 3, ss. 323-351.

"State: Political System", Slovania.Si, http://www.slovenia.si/slovenia/state, (Erişim: 5 Şubat 2016).

"Switzerland's Political System", The Federal Council: The Portal of the Swiss Government, https://www.admin.ch/gov/en/start/federal-council/politicalsystem-of-switzerland.html, (Erişim: 2 Şubat 2016).

“The Cabinet: 12 December 2015 - Present", Embassy of Tanzania, Germany, http:// www.tanzania-gov.de/tanzania/the-cabinet, (Erişim: 2 Şubat 2016).

"The Executive Powers of State", The Presidency, Republic of Ghana, http://www. presidency.gov.gh/executive, (Erişim: 3 Şubat 2016).

TÜİK, "Gelir ve Yaşam Koşulları Araştırması, 2012: En Zengin Kesimin Geliri En Yoksul Kesimin Gelirinin 8 Katı Oldu", Türkiye İstatistik Kurumu Haber Bülteni,13594, 23 Eylül 2013, http://www.tuik.gov.tr/PreHaberBultenleri. do?id=13594 (Erişim: 25 Ekim 2016). 
Liste 4. Parlamentolar Arası Birlik Verilerine göre Avrupa Ülkelerinin Yönetim Sistemi ${ }^{32}$

$\begin{array}{lll}\text { Sira } & \text { Ülke Adı } & \text { Siyasal Rejim Tipi } \\ 1 & \text { Almanya } & \text { Parlamenter } \\ 2 & \text { Andorra } & \text { Parlamenter Eş-Prenslik } \\ 3 & \text { Avusturya } & \text { Parlamenter } \\ 4 & \text { Belçika } & \text { Parlamenter / Anayasal Monarşi } \\ 5 & \text { Beyaz Rusya } & \text { Başkanlık } \\ 6 & \text { Bulgaristan } & \text { Parlamenter } \\ 7 & \text { Çek Cum. } & \text { Parlamenter } \\ 8 & \text { Danimarka } & \text { Parlamenter / Anayasal Monarşi } \\ 9 & \text { Estonya } & \text { Parlamenter } \\ 10 & \text { Fransa } & \text { Yarı-başkanlık } \\ 11 & \text { Hırvatistan } & \text { Parlamenter } \\ 12 & \text { Hollanda } & \text { Parlamenter / Anayasal Monarşi } \\ 13 & \text { İngiltere } & \text { Parlamenter / Anayasal Monarşi } \\ 14 & \text { İrlanda } & \text { Parlamenter } \\ 15 & \text { İspanya } & \text { Parlamenter / Anayasal Monarşi } \\ 16 & \text { İsveç } & \text { Parlamenter / Anayasal Monarşi } \\ 17 & \text { İsviçre } & \text { Yarı-doğrudan Demokrasi } \\ 18 & \text { İzlanda } & \text { Parlamenter } \\ 19 & \text { Kıbrıs } & \text { Başkanlık } \\ 20 & \text { Letonya } & \text { Parlamenter } \\ 21 & \text { Lihtenştayn } & \text { Parlamenter / Anayasal Monarşi } \\ 22 & \text { Litvanya } & \text { Parlamenter } \\ 23 & \text { Lüksemburg } & \text { Parlamenter / Anayasal Monarşi } \\ 24 & \text { Macaristan } & \text { Parlamenter } \\ 25 & \text { Makedonya } & \text { Parlamenter } \\ 26 & \text { Monako } & \text { Parlamenter / Anayasal Monarşi } \\ 27 & \text { Polonya } & \text { Parlamenter } \\ 28 & \text { Romanya } & \text { Yarı-başkanlık } \\ 29 & \text { Rusya } & \text { Yarı-başkanlık } \\ 30 & \text { Sırbistan } & \text { Yarı-başkanlık } \\ 31 & \text { Slovakya } & \text { Parlamenter } \\ 32 & \text { Slovenya } & \text { Parlamenter } \\ 33 & \text { Türkiye } & \text { Parlamenter } \\ 34 & \text { Ukrayna } & \text { Yarı-başkanlık } \\ 35 & \text { Yunanistan } & \text { Parlamenter } \\ & & \end{array}$

Veritabanında Yönetim Bilgisi Eksik Ülkeler

$\begin{array}{lll}36 & \text { Arnavutluk } & \text { Parlamenter } \\ 37 & \text { Bosna Hersek } & \text { Parlamenter } \\ 38 & \text { Finlandiya } & \text { Parlamenter } \\ 39 & \text { İtalya } & \text { Parlamenter } \\ 40 & \text { Karadağ } & \text { Parlamenter } \\ 41 & \text { Kosova } & \text { Parlamenter } \\ 42 & \text { Malta } & \text { Parlamenter } \\ 43 & \text { Moldova } & \text { Parlamenter } \\ 44 & \text { Norveç } & \text { Parlamenter / Anayasal Monarşi } \\ 45 & \text { Portekiz } & \text { Yarı-başkanlık } \\ 46 & \text { San Marino } & \text { Parlamenter }\end{array}$

32 "Parline Database: Parliamentary Oversight Module", Inter-Parliamentary Union, http://www.ipu.org/ parline-e/mod-oversight.asp, (Erişim: 18 Eylül 2016). 


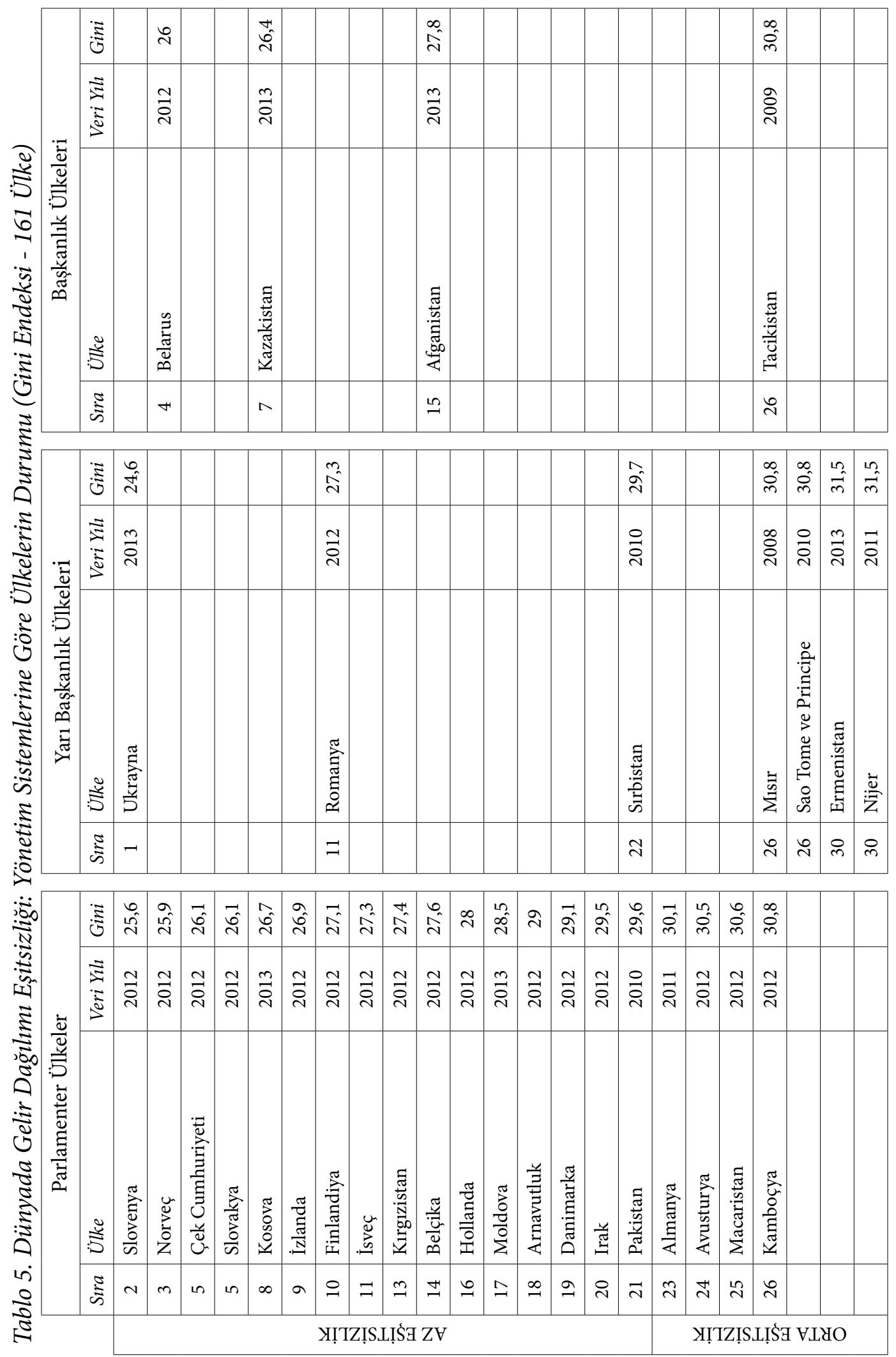




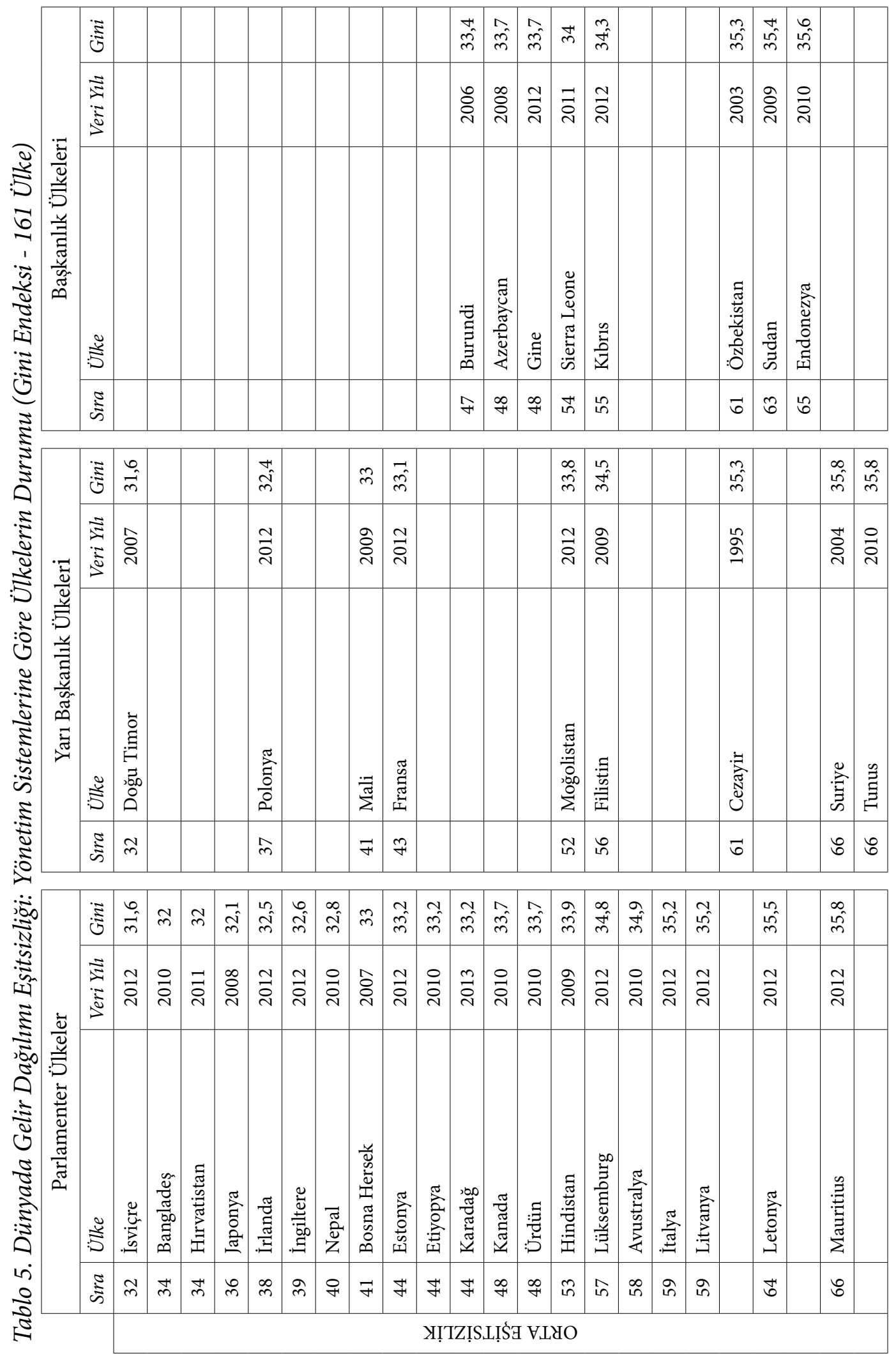




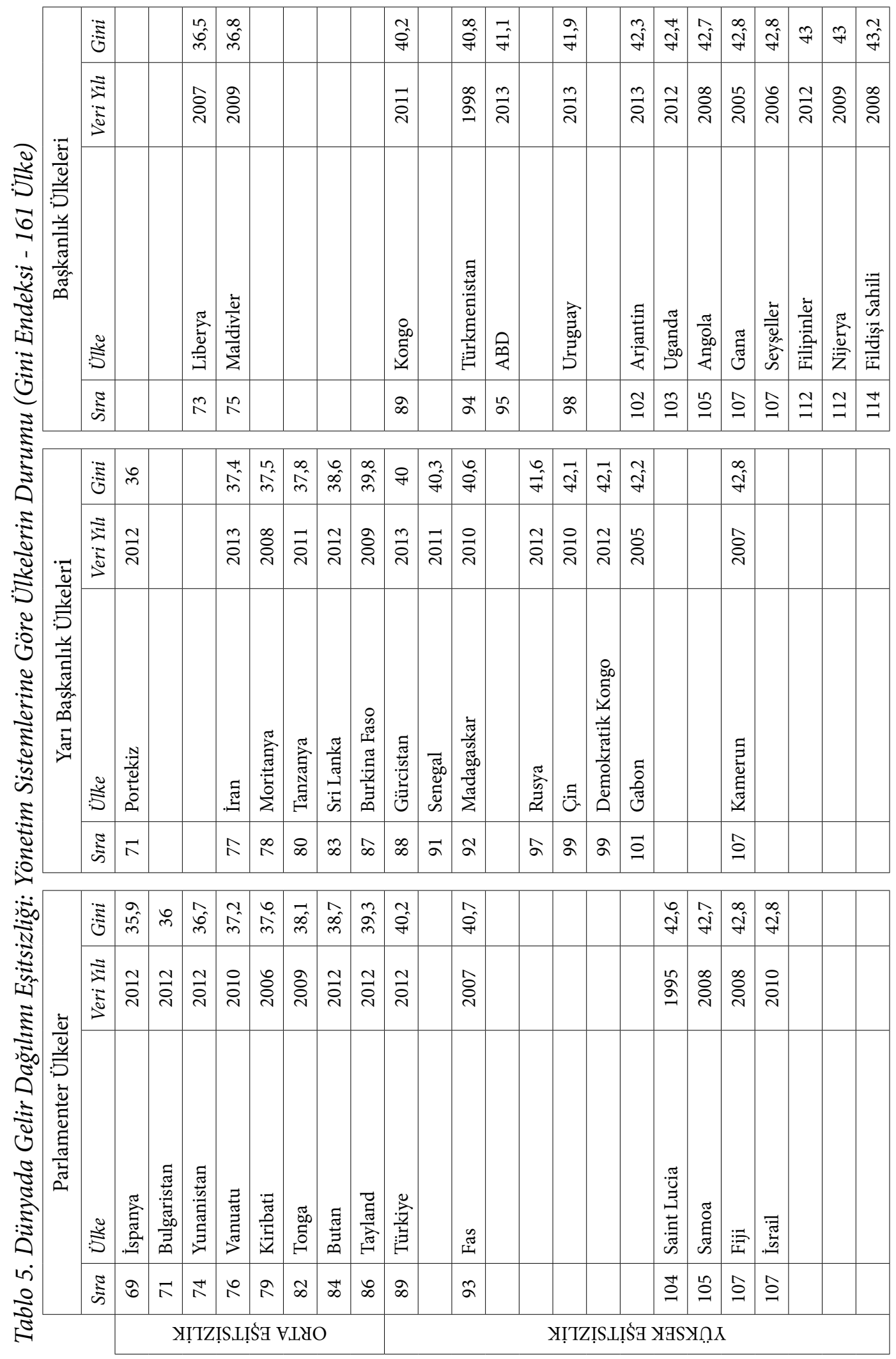




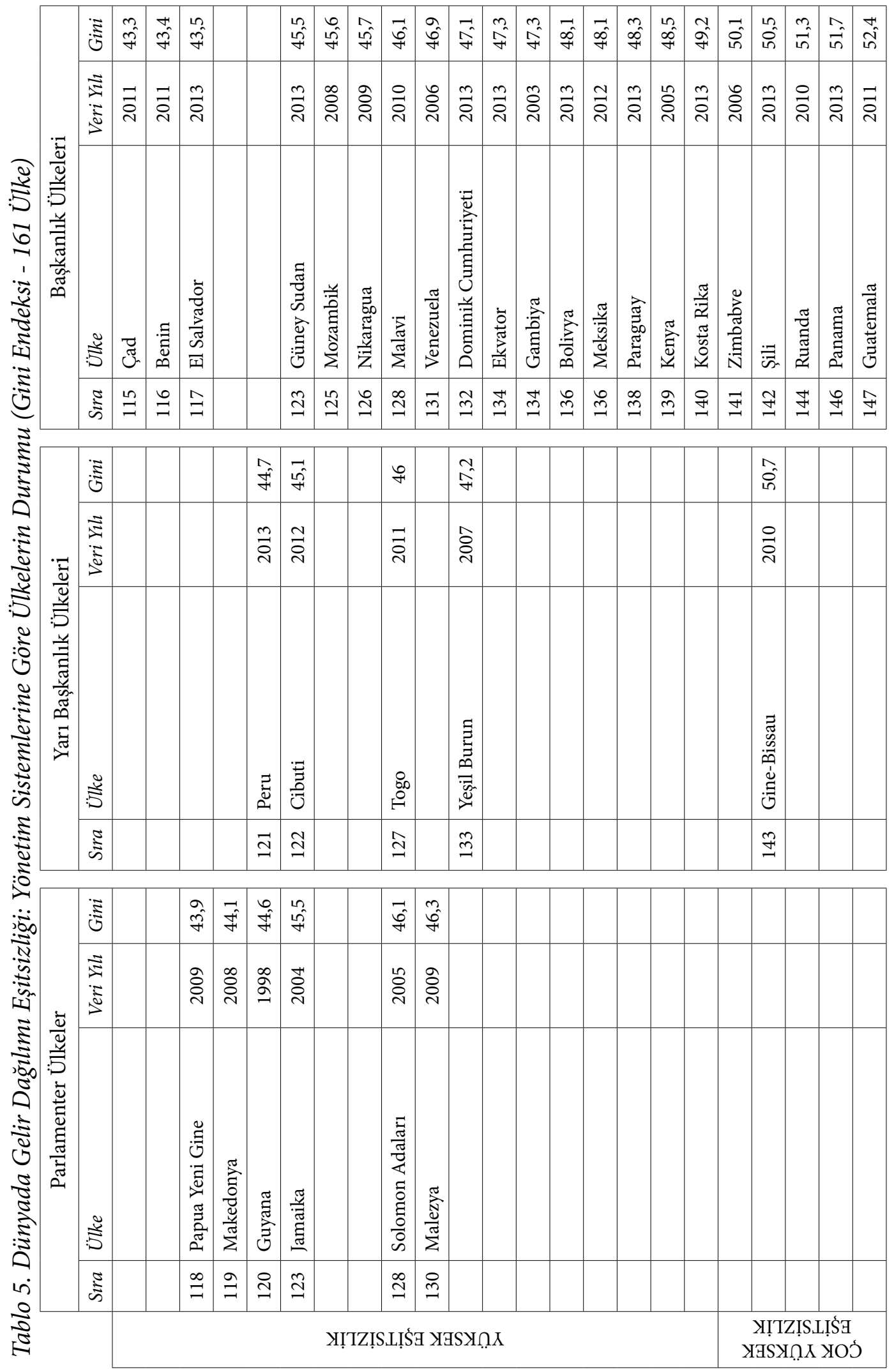




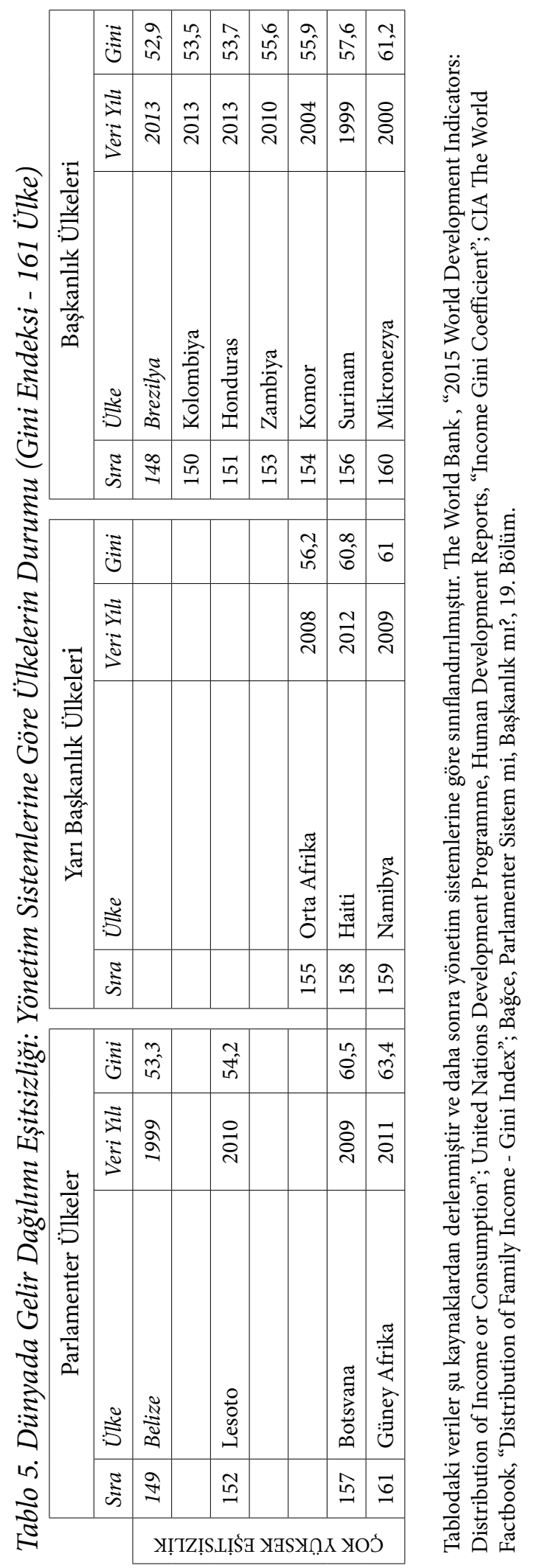




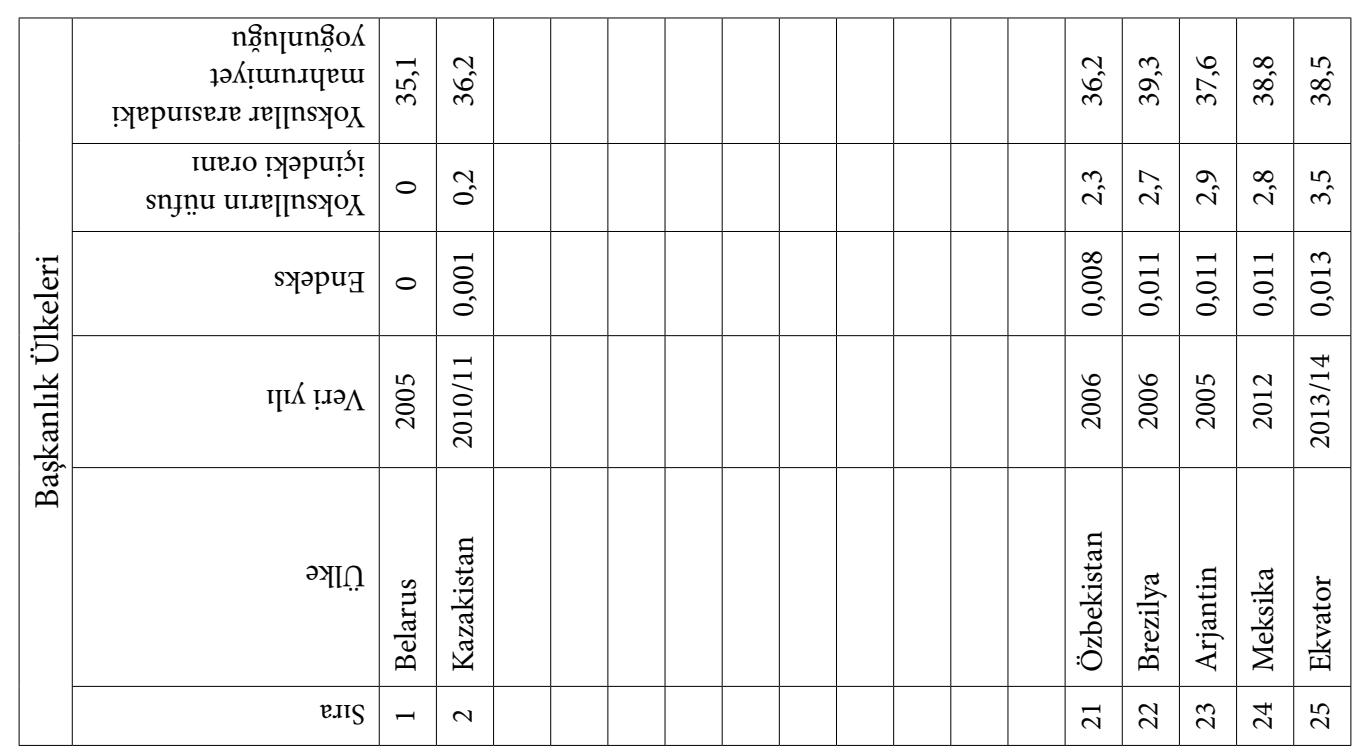

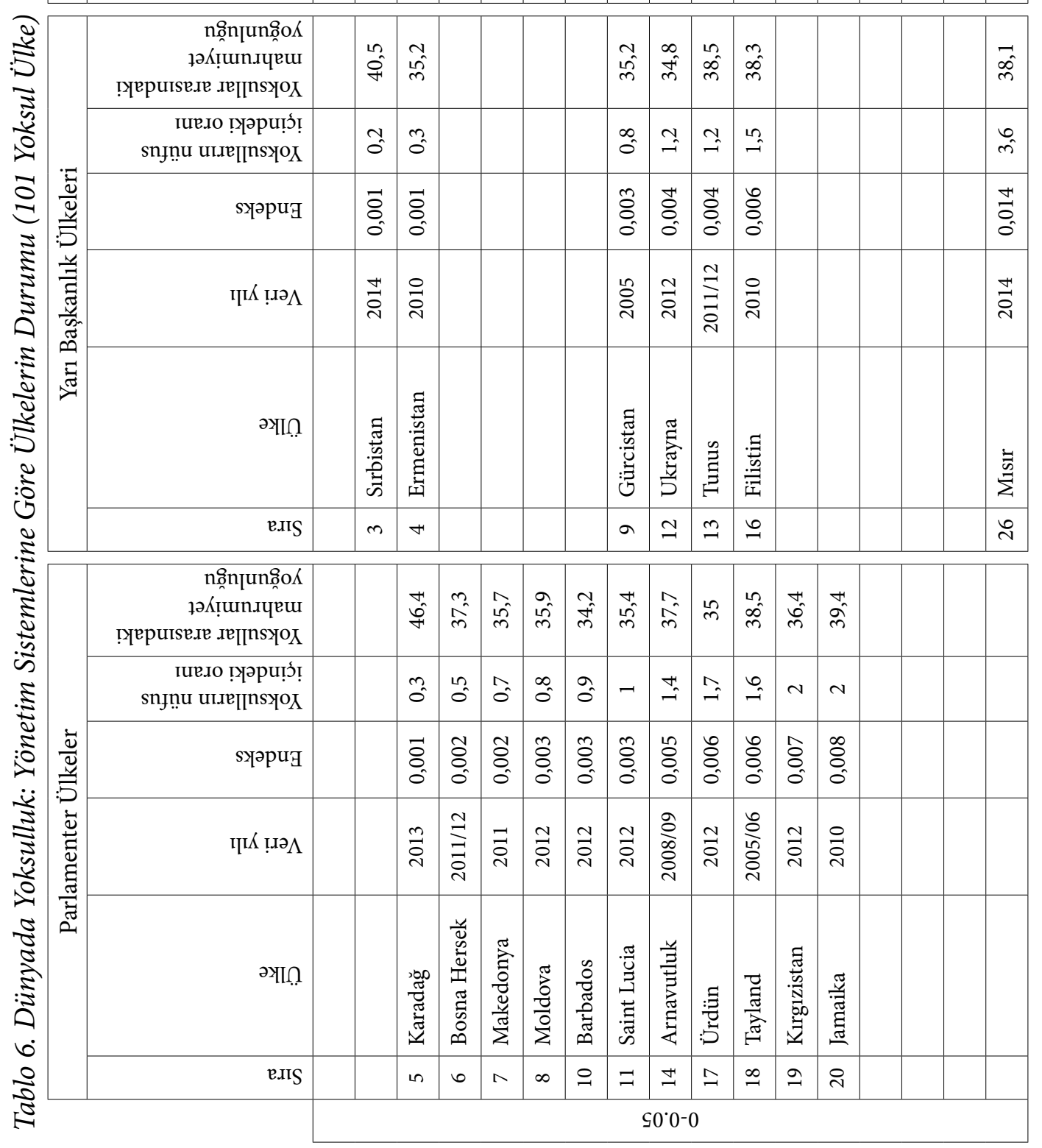




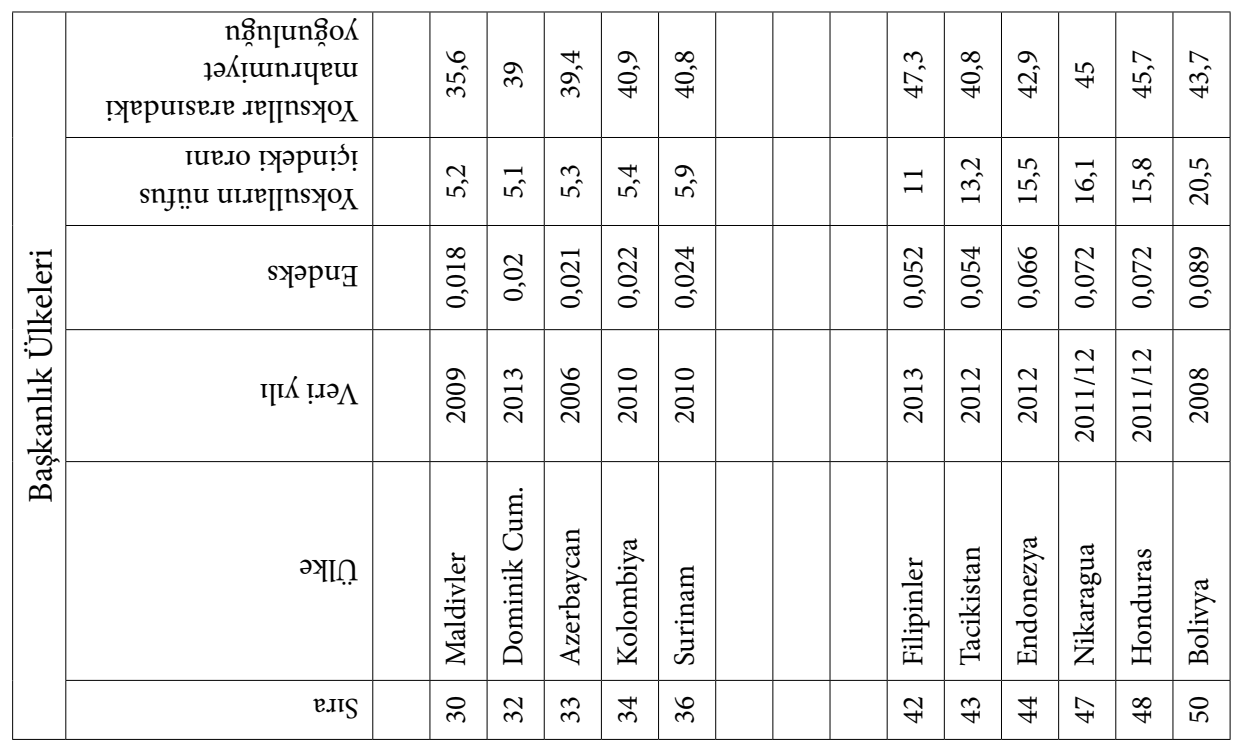

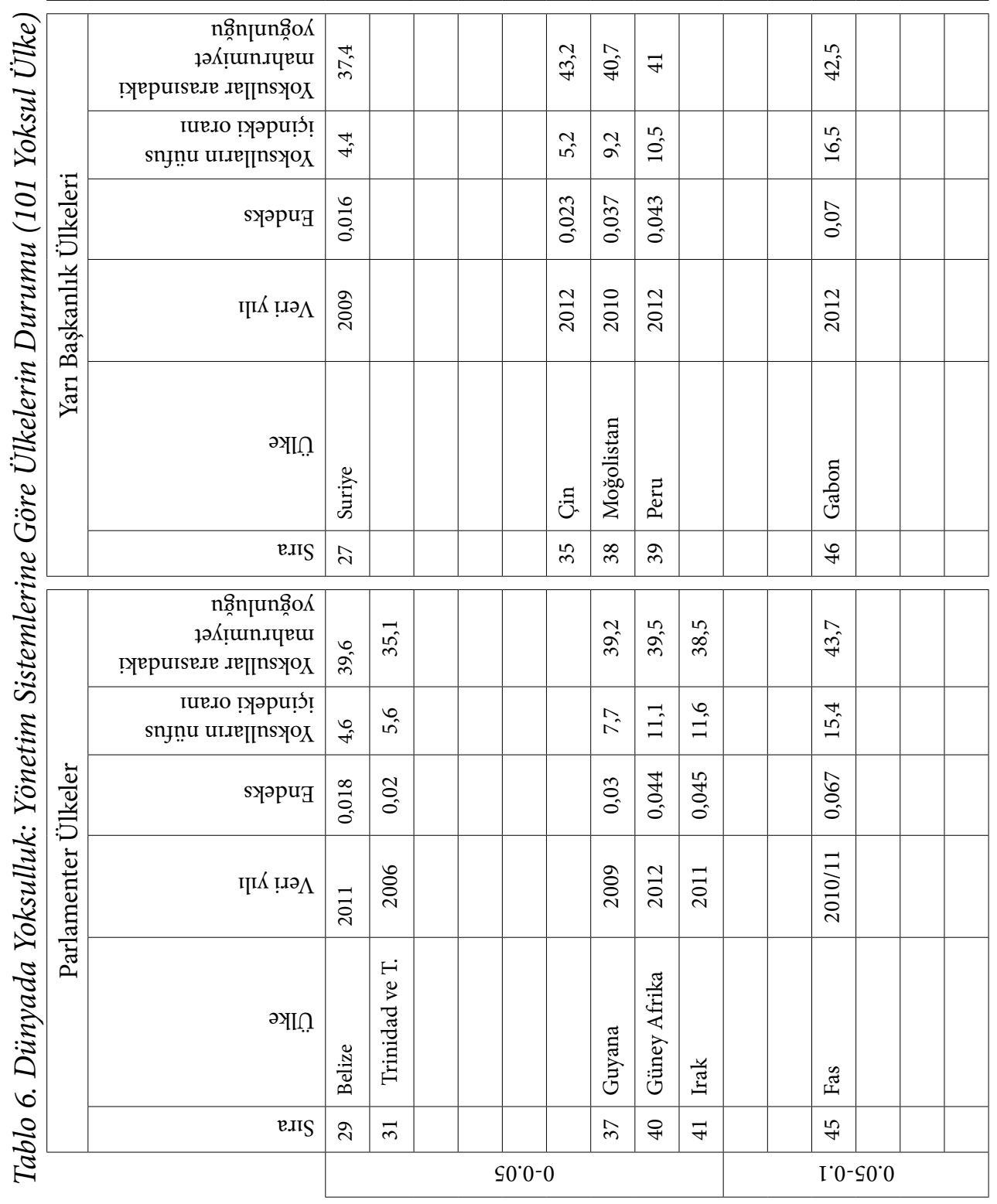




\begin{tabular}{|c|c|c|c|c|c|c|c|c|c|c|c|c|c|c|}
\hline \multirow{6}{*}{ 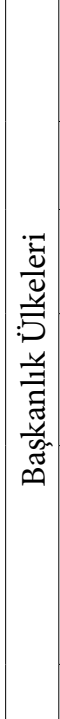 } & 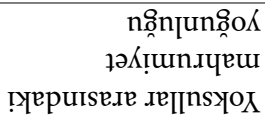 & $\hat{y}$ & $\begin{array}{l}\infty \\
\dot{2} \\
\dot{q}\end{array}$ & $\hat{\partial}$ & if & $\stackrel{\infty}{f}$ & $\begin{array}{l}\infty \\
\mathfrak{g}^{\prime}\end{array}$ & $\begin{array}{l}\infty \\
\hat{b}^{\circ}\end{array}$ & $\stackrel{2}{\sigma}^{2}$ & $\begin{array}{l}\infty \\
\hat{1} \\
\hat{n}\end{array}$ & $\begin{array}{l}6 \\
\hat{n}^{n}\end{array}$ & $\stackrel{H}{n}$ & $\overrightarrow{0}$ & 象 \\
\hline & 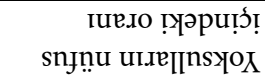 & $\hat{\vec{N}}$ & 苞 & $\stackrel{m}{i}$ & $\hat{\tilde{m}}$ & $\begin{array}{l}\infty \\
\stackrel{f}{f}\end{array}$ & $\begin{array}{l}\text { bे } \\
b^{0}\end{array}$ & त̂ & 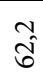 & $\begin{array}{l}\hat{\infty} \\
\hat{n}^{\prime}\end{array}$ & $\begin{array}{l}\infty \\
\text { in }\end{array}$ & 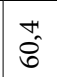 & 宅 & 8 \\
\hline & sуәрия & $\begin{array}{l}\hat{A} \\
0 \\
0\end{array}$ & 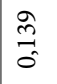 & $\stackrel{M}{\frac{1}{1}}$ & $\begin{array}{l}\vec{\infty} \\
\overrightarrow{0}\end{array}$ & స్ & \begin{tabular}{l}
$\vec{\infty}$ \\
\multirow{0}{0}{}
\end{tabular} & $\begin{array}{c}\text { on } \\
\tilde{m}_{2} \\
0\end{array}$ & $\begin{array}{l}1 \\
0 \\
0 \\
0\end{array}$ & $\overrightarrow{m_{2}}$ & $\vec{\pi}$ & $\begin{array}{c}\pi \\
\tilde{N} \\
0\end{array}$ & 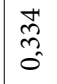 & $\begin{array}{l}n \\
m \\
0\end{array}$ \\
\hline & 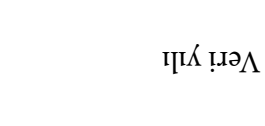 & $\stackrel{+}{\stackrel{4}{i}}$ & $\overrightarrow{\vec{\sim}}$ & $\stackrel{\sim}{\tilde{ก}}$ & $\underset{\sim}{\stackrel{\sim}{*}}$ & 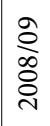 & 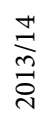 & $\stackrel{\text { mे }}{\stackrel{N}{2}}$ & 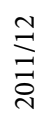 & $\underset{\Xi}{\Xi}$ & $\stackrel{\text { ì }}{2}$ & 离 & 옥 & 옹 \\
\hline & 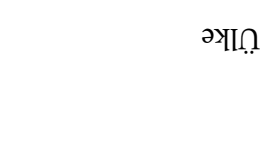 & $\begin{array}{l}\text { है } \\
\text { है } \\
\text { है } \\
\text { N }\end{array}$ & 莺 & $\begin{array}{l}\text { 节 } \\
\text { an }\end{array}$ & 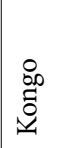 & 芯 & $\begin{array}{l}\text { त्रें } \\
\text { त्ञ } \\
\text { N }\end{array}$ & 莺 & 表 & 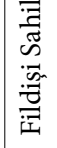 & 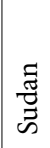 & 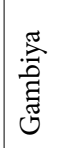 & 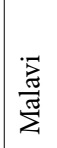 & 芶 \\
\hline & exIS & ก & in & $\stackrel{\infty}{i \infty}$ & 8 & ठ & $R$ & H & $\stackrel{10}{\wedge}$ & $\therefore$ & $\infty$ & న & $\vec{\infty}$ & $\infty$ \\
\hline
\end{tabular}

\begin{tabular}{|c|c|c|c|c|c|c|c|c|c|c|c|c|c|}
\hline \multirow{6}{*}{ 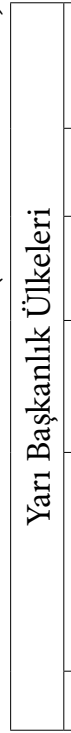 } & 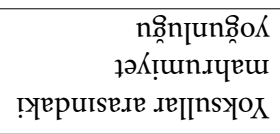 & & $\stackrel{m}{2}$ & fi & f & & & & \begin{tabular}{l|l}
$\infty$ & $m$ \\
$\hat{n}$ & $\hat{n}$ \\
$n$ & 0
\end{tabular} & in & 定 & 苻 & $\begin{array}{l}\text { ố } \\
\text { in }\end{array}$ \\
\hline & 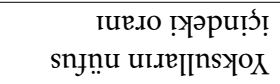 & & के & $\mid \begin{array}{l}n \\
\text { fn } \\
m\end{array}$ & F & & & & for & $\overrightarrow{8}$ & $\tilde{n}$ & $\begin{array}{l}\hat{b} \\
\text { மे }\end{array}$ & 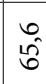 \\
\hline & sуәрия & & $\begin{array}{c}\text { के } \\
\text { के }\end{array}$ & 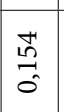 & $\frac{m}{2}$ & & & & 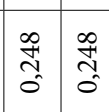 & \begin{tabular}{l}
1 \\
\multirow{2}{N}{} \\
0 \\
0
\end{tabular} & $\begin{array}{l}n \\
\infty \\
1 \\
0 \\
0\end{array}$ & $\begin{array}{l}2 \\
\text { oे } \\
\text { ô }\end{array}$ & ले \\
\hline & ч[น & & ¿্ণ & 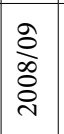 & $\stackrel{m}{\stackrel{\sim}{i}}$ & & & & $\overrightarrow{\tilde{N}} \tilde{\stackrel{\sim}{n}}$ & 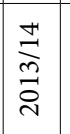 & تี่ & ت্ं & $\stackrel{\circ}{\circ}$ \\
\hline & әУโగֶ & & 音 & 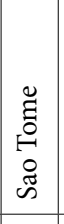 & 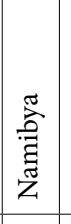 & & & & 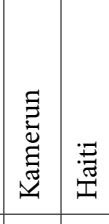 & $\begin{array}{c}8 \\
8 \\
\stackrel{\circ}{\ominus} \\
\end{array}$ & 䔍 & 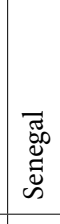 & 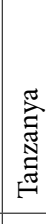 \\
\hline & exis & & in & in & $\overrightarrow{6}$ & & & & \begin{tabular}{l|l}
8 & 6 \\
\end{tabular} & $\infty$ & $\Re$ & $\stackrel{0}{1}$ & $\infty$ \\
\hline \multirow{6}{*}{ 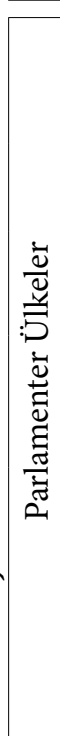 } & 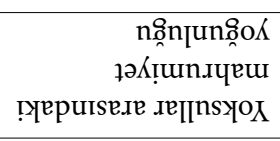 & $\hat{\tilde{F}}$ & $\hat{f}$ & $\bar{f}$ & & $\overrightarrow{0}$ & के & $\overrightarrow{\hat{\imath}}$ & & $\ddot{a}$ & $\hat{\hat{n}}$ & & \\
\hline & 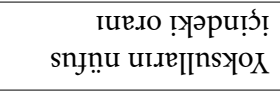 & $\stackrel{\sim}{\stackrel{N}{N}}$ & $\overrightarrow{0}$ & $\hat{n}^{2}$ & & ईे & $\stackrel{N}{f}$ & f & & $\underset{n}{i n}$ & $\hat{\tilde{n}}$ & & \\
\hline & sұәрü & $\begin{array}{l}\Rightarrow \\
0\end{array}$ & ì & $\begin{array}{l}0 \\
2 \\
0 \\
0\end{array}$ & & $\begin{array}{l}\tilde{z} \\
\tilde{\sigma} \\
\end{array}$ & 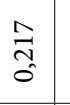 & $\begin{array}{l}3 \\
\tilde{\sigma}\end{array}$ & & 满 & 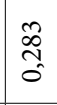 & & \\
\hline & 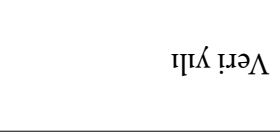 & $\stackrel{\text { ڤे }}{\circ}$ & & ठิે & & $\stackrel{2}{\circ}$ & $\vec{i}$ & 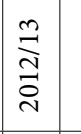 & & $\overrightarrow{\text { จे }}$ & $\stackrel{2}{2}$ & & \\
\hline & әҮโดֶ & 苂 & 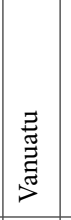 & 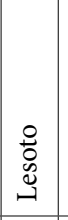 & & 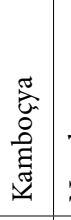 & 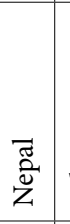 & 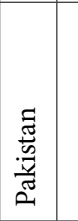 & & 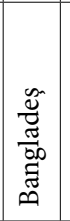 & 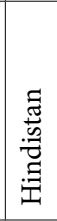 & & \\
\hline & e.IIS & $\vec{n}$ & $n$ & in & & $\widetilde{\sigma}$ & $\tilde{6}$ & 18 & & 8 & 5 & & \\
\hline & & & $\tau^{*} 0^{-}$ & & & & & & $0-z^{\circ} 0$ & & & & \\
\hline
\end{tabular}




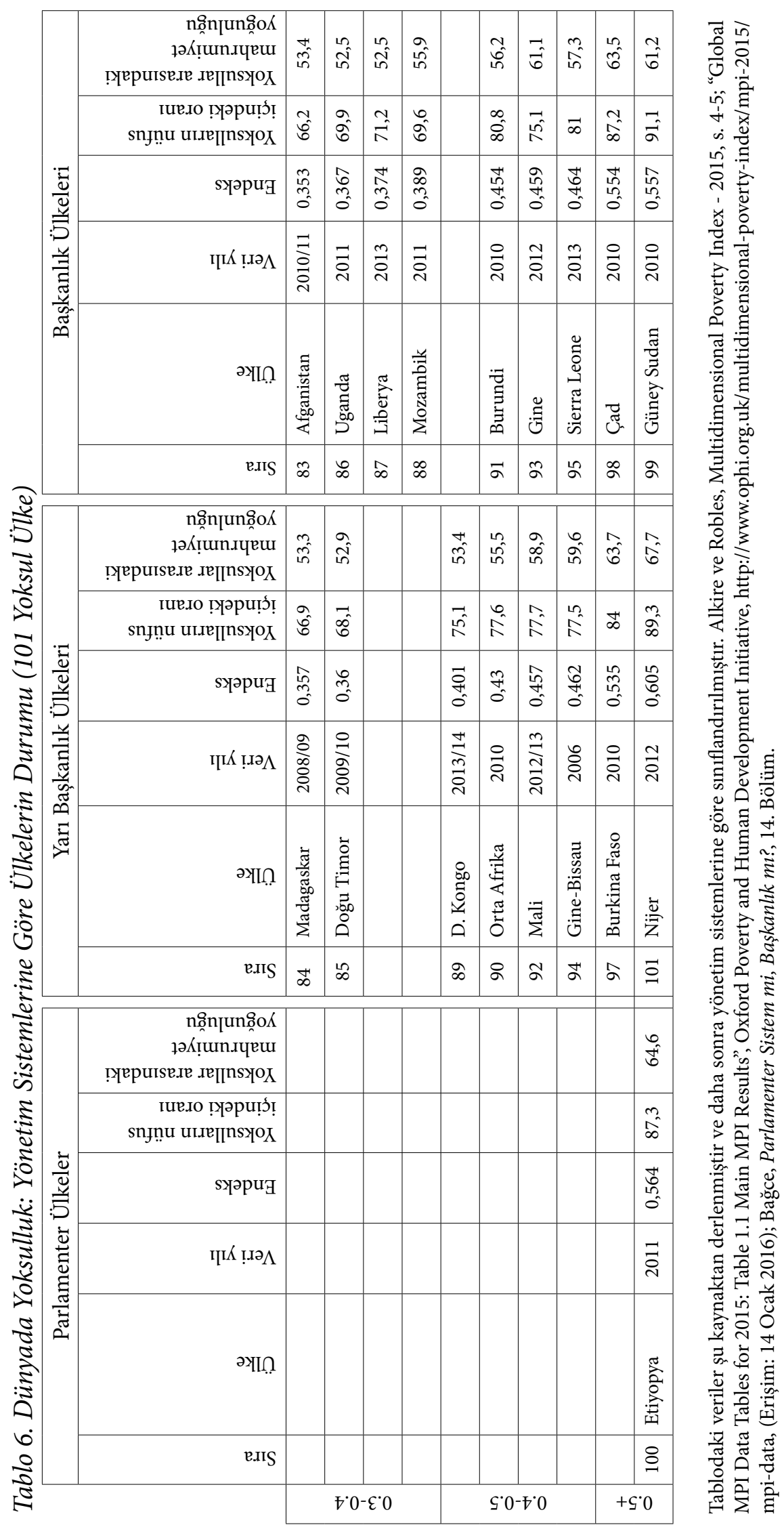




\title{
Inequality of Income Distribution and Poverty in Countries Governed by Parliamentary and Presidential Systems
}

\author{
H. EMRE BAĞCE
}

\begin{abstract}
In this article, parliamentary, presidential and semi-presidential governments are examined in terms of inequality of income distribution and poverty. In this way, it is aimed that hypothetical discussions about the advantages or disadvantages of political systems can be overcome and more refined knowledge about the nature of political systems can be reached through the concrete results of the analyses. In the first part of the study, it is determined and classified which countries in the world are governed by parliamentary system and which are governed by presidential and semi-presidential systems. In the second part, inequality of income distribution, measured by Gini Index (World Bank estimate) in more than one hundred and fifty countries of the world are reviewed and compared by parliamentary, presidential and semi-presidential systems. And in the third part, the poverty levels of one hundred and one countries in Multidimensional Poverty Index, which is developed by Oxford Poverty and Human Development Initiative, are assessed in terms of their affiliation to the competing political systems. According to the results of the study, it is found that inequality of income distribution is less in the countries governed by the parliamentary system, and in a similar way, it is more favorable in terms of poverty. Presidential and semi-presidential countries were found to be in somewhat negative condition in both categories.
\end{abstract}

Keywords: Parliamentary system, Presidential system, Semi-presidential system, Inequality of income distribution, Gini index, Poverty. 